\title{
Contribution of groundwater to the outflow from ungauged glacierized catchments: a multi-site study in the tropical Cordillera Blanca, Peru
}

Michel Baraer ${ }^{1}$; Jeffrey McKenzie ${ }^{2}$; Bryan Mark ${ }^{3}$; Ryan Gordon ${ }^{4}$; Jeffrey Bury ${ }^{5}$; Thomas Condom $^{6}$; Jesus Gomez ${ }^{7}$; Sara Knox ${ }^{8}$; Sarah Fortner ${ }^{9}$

${ }^{1}$ Construction Engineering, ÉTS, Université du Quebec, Montreal, Quebec H3C 1K3, Canada

${ }^{2}$ Department of Earth and Planetary Sciences, McGill University, Montreal, Quebec H3A 2A7, Canada

${ }^{3}$ Geography, Ohio State University, Columbus, Ohio 43210, USA

${ }^{4}$ Earth Sciences, Syracuse University, Syracuse, New York 13244, USA

${ }^{5}$ Environmental Studies, University of California, Santa Cruz, California, USA

${ }^{6}$ LTHE, Institut de Recherche pour le Developpement, Saint Martin d'Heres, 38400, France

${ }^{7}$ Parque Nacional Huascarán, Ministerio del ambiente, Huaraz, Peru

${ }^{8}$ Department of Environmental Science, Policy and Management, University of California, Berkeley, California, USA

${ }^{9}$ Byrd Polar Research Center, The Ohio State University, Columbus, Ohio 43210, USA

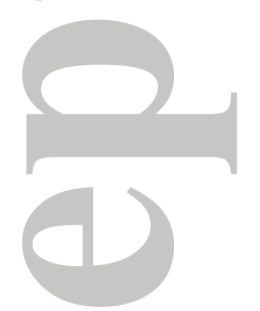

This is the peer reviewed version of the following article:

Baraer, M., McKenzie, J., Mark, B. G., Gordon, R., Bury, J., Condom, T., ... Fortner, Sarah K. (2015). Contribution of groundwater to the outflow from ungauged glacierized catchments: a multi-site study in the tropical Cordillera Blanca, Peru. Hydrological Processes 29(11), 2561-2581.

This article may be used for non-commercial purposes in accordance with Wiley Terms and Conditions for Self-Archiving.

This article has been accepted for publication and undergone full peer review but has not been through the copyediting, typesetting, pagination and proofreading process which may lead to differences between this version and the Version of Record. Please cite this article as doi: 10.1002/hyp.10386 


\begin{abstract}
The rapid retreat of the glaciers of the Cordillera Blanca is having a noticeable impact on the downstream hydrology. Although groundwater is a critical hydrologic component that sustains stream flows during the dry season, its characteristics and its contribution to downstream hydrology remain poorly understood. In this study, we analyze the hydrochemical and isotopic properties of potential hydrologic sources mixing in surface streams to characterize the proglacial hydrology in four glacially fed watersheds within the Cordillera Blanca, Peru. Water samples from streams, glacial melt and groundwater were collected in 2008 and 2009 and analyzed for major ions and stable isotopes $\left(\delta^{18} \mathrm{O}\right.$ and $\left.\delta^{2} \mathrm{H}\right)$. Multivariate analysis of variance was used first to identify the hydrochemical and isotopic characteristics (tracers) of the water samples that depend primarily on the water source. Then several analyses, including hierarchical cluster analysis and mixing diagrams, were performed using these source-dependent tracers, enabling a qualitative description of the key hydrological mechanisms that characterize the study watersheds. Finally, we applied a multicomponent spatial mixing model, the Hydrochemical Basin Characterization Method (HBCM), to quantify the contributions of different water sources to the outflow from the four watersheds. The HBCM results show that groundwater is a major component of the discharge during the dry season and that the groundwater contribution to outflow is greater than $24 \%$ in all of the valleys. The results are used to develop a conceptual proglacial hydrological model of the Cordillera Blanca valleys. Talus and avalanche cones are identified as key components of the hydrology of the valleys. The talus deposits collect precipitation and runoff from higher elevations (approximately $400 \mathrm{~m}$ above the valley floor) and have a residence time that is long enough to actively release substantial volumes of water throughout the dry season.
\end{abstract}

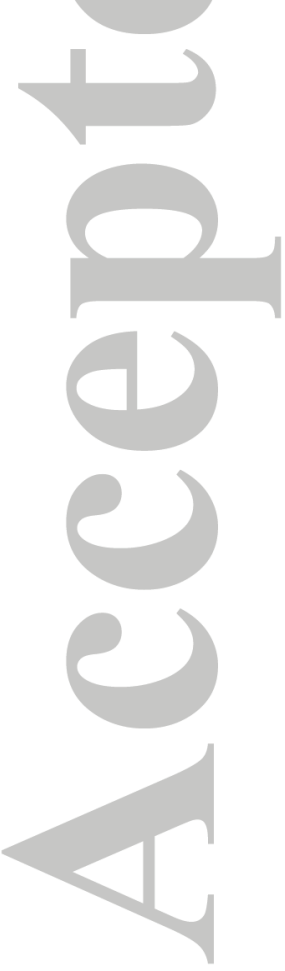

This article is protected by copyright. All rights reserved. 


\section{1-Introduction}

The world's tropical glaciers have retreated over the last century (Rabatel et al., 2013), which has altered the seasonality of the proglacial hydrology and raised concerns about downstream water supplies (Mark and Seltzer, 2003). The Santa River (Rio Santa), which drains the western side of the Cordillera Blanca in Peru, has exhibited a decline in dry season discharge that is related to glacial retreat (Baraer et al., 2012). Such hydrological changes have significantly altered the seasonal availability of water in the region and pose critical risks to the local population, who are highly dependent on these resources for their livelihoods (Bury et al., 2011). In the context of the general decrease in regional water resources, households have also been notably impacted by the disappearance of many of the perennial and intermittent springs that provide potable water (Mark et al., 2010).

During the tropical Andean dry season, when rainfall is low or absent, natural hydrologic storage systems release water that accumulated during the rainy seasons. Glaciers are the most extensively studied water storage system within these proglacial valleys (Mark and Seltzer, 2003; Chevalier et al., 2004; Coudrain et al., 2005; Pouyaud et al., 2005; Bradley et al., 2006; Juen et al., 2007), whereas groundwater systems, despite their importance, are poorly understood (Mark and McKenzie, 2007). Using a hydrochemical mixing model, Baraer et al. (2009) found that at the scale of a single glacierized watershed (with $7 \%$ of the watershed covered by glaciers) in the Cordillera Blanca, groundwater was the largest contributor to the catchment outflow for most of the studied dry seasons and that the flux of groundwater was temporally variable. Despite these findings, many aspects of the groundwater system of the Cordillera Blanca, such as its spatial variability and the processes that control groundwater flow, remain poorly characterized in the largely ungauged glacier valleys.

In the present study, we further investigate the hydrogeological system of alpine glacierized catchments using hydrochemical and stable isotopic parameters. Numerous studies have demonstrated the utility of using hydrochemistry and stable isotopes of water to characterize hydrologic dynamics in glacierized catchments (Clow et al., 2003; Strauch et al., 2006; Ryu et al., 2007; Roy and Hayashi, 2009; Crossman et al., 2011; Yang et al., 2011; La Frenierre and Mark, 2014). These methods are powerful research tools in areas where conventional in situ hydrological and hydrogeological methods are difficult to deploy given a lack of instrumentation (Mark et al., 2005).

The hydrochemical composition of natural water is strongly influenced by the porous substrate through which it flows (Sidle, 1998). Weathering processes that generate hydrochemical signatures can be physical, biological or chemical and are characterized by a reaction type (e.g., dissolution) and a reaction time. Rock/soil contact time is usually positively correlated with the total solute concentration in the water. Chemical weathering rates usually increase if the rate of physical or mechanical weathering increases (Langmuir, 
1997). Cation exchange processes and dissolution processes also play important roles in controlling the chemical composition of water (Yamanaka et al., 2005). These temperaturedependent mechanisms cause the geomorphic parameters of the watershed (e.g., rock/soil characteristics or relief), climate, vegetation and residence time to be important environmental factors that influence the chemistry of the meteoric water that flows through a watershed (Drever, 2005).

Unlike hydrochemical characteristics, the isotopic composition of shallow groundwater is effectively unaltered by interactions with the porous media during its passage through an aquifer at low temperatures (below $60^{\circ} \mathrm{C}$ ) (Gat, 2010). In the absence of phase changes or fractionation along the flow path, which are not normally observed in shallow aquifers, the stable isotope values of oxygen and hydrogen remain constant (Clark and Fritz, 1997; Kortelainen, 2011).

In the tropical Andes, the seasonal pattern of the isotopic values of precipitation is in phase with the volume of precipitation; this is the so-called "amount effect" (Vuille et al., 2003; Vimeux et al., 2005; Risi et al., 2008). Rainy months therefore largely control the yearly mean $\delta^{18} \mathrm{O}$ and $\delta^{2} \mathrm{H}$ values of precipitation (Gonfiantini et al., 2001), which causes the spatial distribution of $\delta^{18} \mathrm{O}$ and $\delta^{2} \mathrm{H}$ in the Andean region to be dominated by the altitude effect (Rozanski and Araguas, 1995). These characteristics have led groundwater isotopic signaturebased methods to become well established for identifying the origins and pathways of groundwater recharge (McKenzie et al., 2001; Barbieri et al., 2005; Blasch and Bryson, 2007; Kohfahl et al., 2008; Jeelani et al., 2010; Parisi et al., 2011; Wassenaar et al., 2011; Windhorst et al., 2013).

The objectives of this paper are to develop a further understanding of the contribution of groundwater to valley outflow and to provide a first quantitative estimate of dry season groundwater volumes in four glacierized valleys in the Cordillera Blanca, Peru, based on water samples collected in 2008 and 2009. To reach these objectives, we utilize a distributed mixing model that is tested here for the first time in a multi-site study. We organize the paper in 7 main sections as follows. After this introduction (section 1), we describe the geography and proglacial valley landscape features in the study site (section 2), followed by the presentation of the mapping and sampling methods (section 3). Next, we detail the sequential method and results of the hydrological mechanisms and flowpath analysis (section 4): selection of natural tracers that can be used to identify the sources of surface water samples; use of these tracers to identify the main sources of groundwater; and analysis of how the main sources of groundwater contribute significantly to the watersheds outflow using the isotopic signatures and hydrochemical characteristics of the samples. We then quantify the contribution of groundwater to the watershed flows using a distributed mixing model (section 5). In discussion (section 6) we identify dry season hydrogeological features common to the four valleys with a conceptual model, and compare findings to studies of similar systems in environments other than the tropical Andes. We conclude (section 7) with a synthesis of three new insights and recommended further research into hydrologic processes of Andean proglacial hydrogeology. 


\section{2-Study site}

\subsection{Geographic setting}

This study is situated within the SW draining glacier valleys of the Cordillera Blanca, Peru (Figure 1). The Cordillera Blanca has the largest glaciated surface area in the tropics (Suarez et al., 2008). The glacial coverage of the Cordillera Blanca decreased from $800-850 \mathrm{~km}^{2}$ in 1930 to slightly less than $600 \mathrm{~km}^{2}$ at the end of the $20^{\text {th }}$ century (Georges, 2004).

Subsequently, glaciers have continued shrinking to reach an area of $482 \mathrm{~km}^{2}$ in 2010 (Burns and Nolin, 2014). The region is characterized by strong seasonal precipitation, which is typical of the outer tropics; more than $80 \%$ of the precipitation falls between October and April, and almost no precipitation falls during the austral winter months of June to August. In the upper Rio Santa watershed, glacial melt (ice and snow melt from glaciers) provides 10 to $20 \%$ of the total annual river discharge and may exceed $40 \%$ in the dry season (Mark et al., 2005). As is typical of the tropics, the daily temperature range is much larger than the seasonal changes in the daily mean temperature. Unlike glaciers at mid- to high latitudes, the absence of thermal seasonality in the tropics permits continuous glacier ablation throughout the year (Kaser and Georges, 1999).

Geologically, the Cordillera Blanca is approximately 10 million years old and lies on the magmatic Andean arc, which was formed by the subduction of the Nazca plate under the South America plate. The bedrock on the western side of the Cordillera Blanca was exhumed by the NW-SE-trending Cordillera Blanca Detachment Fault, and most (80 to 90\%) of the bedrock is composed of batholiths with high silicate content; the remainder of the bedrock is composed of isolated bodies of tonalite and diorite (McNulty et al., 1998). The Jurassic Chicama Formation comprising the eastern side of the Cordillera Blanca (Petford and Atherton, 1992) contains weathered shale, argillite and sandstone, and some areas of extensive iron sulfides, likely as pyrite (Fortner et al., 2011). The geology near the southwest headwaters of the Rio Santa basin is dominated by volcanic ignimbrite of the Calipuy Formation, which is composed of sequences of terrestrial andesite, dacite and rhyolite (Myers, 1975).

\subsection{Proglacial valley landscape features}

Sequences of glacial advance and retreat, together with episodes of paraglacial sidewall mass wasting, have produced valley depositional systems (Goldthwait and Matsch, 1989;

Ballantyne, 2002) that are composed of differentiated layers of landslide deposits and glacial, glaciolacustrine, glaciofluvial, eolian and/or alluvial sediments. The Andes have experienced several glacial cycles over the past two million years (Menzies, 2002), and the last local glacial maximum is estimated to have occurred between 14,000 and 38,000 years ago (Rodbell, 1993; Smith et al., 2005). The Cordillera Blanca glacier valleys studied here have geomorphic evidence of at least four moraine stabilizations during the last glacial stage, and 
have thus likely been filling with sedimentary processes dating from $\sim 12,000$ years before present (i.e. Smith and Rodbell, 2010).

Hydrogeologically, these systems can be considered a network of areas with distinct hydraulic conductivities and storage capacities (Van de Griend et al., 1986). For example, the glaciolacustrine deposits often behave as aquitards or aquicludes (Parriaux and Nicoud, 1993), whereas the coarse-grained proglacial deposits often have high porosity and permeability (Meriano and Eyles, 2003; Knutsson, 2008; Robinson et al., 2008).

The glaciated valleys of the Cordillera Blanca are characterized by "pampas," landforms defined here as high altitude, low-gradient valley-bottom areas that likely formed by the paludification of moraine-dammed lakes. Pampas are characterized by organic-rich unconsolidated material that overlies glacial deposits (Mark and McKenzie, 2007) and have similar attributes to paramos, the natural grasslands of the northern Andes that are critically important for regional water resources (Girard, 2005; Buytaert et al., 2006). Like paramos, pampas are located at high elevations in the Andes; they are treeless and have a topsoil layer that is composed of organic matter. When locally saturated they can also contain more organic material akin to "bofedales" (i.e. Squeo et al., 2006). These common characteristics indicate that pampas can potentially store groundwater for release during the dry season. Talus and avalanche cones are omnipresent features in glaciated valleys in the Cordillera Blanca. Field observations estimate the sidewall deposits are between 70 and 400 meters long. Similar sidewall deposits in different alpine environments (Benn and Evans, 1998), including in the nearby Cordillera Real (Francou, 1989) are reported having a slope of 35\%. Applied to the side deposit length estimates, this 35\% slope suggests the talus and avalanche cones of the Cordillera Blanca are between 60 and 230 meters high. The slope deposits are distributed nearly continuously and surround the entire valley, which allows the flow from the rock faces to pass through the slope deposits (Caballero et al., 2002). Springs that emanate from the valley floor at the base of sidewall deposits are common in pampas. This type of spring has been shown to play a key hydrological role in the base flows of alpine environments (Roy and Hayashi, 2009; Langston et al., 2011; McClymont et al., 2011; Muir et al., 2011), including the tropical valley of the Zongo glacier in Bolivia (Caballero et al., 2002), which makes them of specific interest for the present study.

We selected the Llanganuco, Quilcayhuanca, Yanamarey and Pumapampa watersheds (Figure 1) because they are representative of the numerous proglacial valleys in the Cordillera Blanca that drain into the Rio Santa. These watersheds are distributed across the latitudinal span of the mountain range and have a combined area of $250 \mathrm{~km}^{2}$. The selected watersheds provide a wide range of glacierized areas, geological characteristics and pampa coverage (Table 1). For example, Llanganuco is located in the northern half of the Cordillera Blanca, where the valleys are deeply incised and the valley walls are nearly vertical. In contrast, Pumapampa is located at the southern end of the range and has gentler topography and a smaller elevation gradient between the bottom of the valley and the watershed divide. 


\section{3- Mapping and sampling methods}

Characterization of the hydrogeology of the Cordillera Blanca valleys required mapping glacier coverage and geology for the selected Rio Santa tributary watersheds, then identifying, classifying and sampling surface waters and potential water sources that feed the main stream of each watershed (defined as the water body that flows from the highest identified water source to the watershed outlet).

\subsection{Mapping glaciers change and geology coverage}

The glacierized areas of each selected Rio Santa tributary valley were evaluated using the 2005 Global Land Ice Measurements from Space (GLIMS) database (Racoviteanu, 2005). Based on previous works (Baraer et al., 2012), the uncertainty in glacierized area estimation is evaluated to be below 5\%. Llanganuco has the largest glacierized area $(41.5+/-2 \%)$, and Yanamarey is the least glacierized $(6.3+/-0.5 \%)$. The geological characteristics of the four watersheds were extracted from geological maps (Selveradjou et al., 2005). Llanganuco has the largest area of plutonic formations, followed by Quilcayhuanca, Yanamarey and Pumapampa. Yanamarey and Quilcayhuanca are dominated by metasedimentary rocks, whereas Pumapampa is primarily composed of the Calipuy volcanic ignimbrites. The areas of the pampas were estimated using an Advanced Spaceborne Thermal Emission and Reflection Radiometer (ASTER) satellite imagery-derived Digital Elevation Model (DEM) with a cell size of $30 \mathrm{~m}$. Pampa areas were defined as valley bottom regions with average slopes less than or equal to $10^{\circ}$ and a minimum elevation greater than $3500 \mathrm{~m}$ above sea level. The pampa coverage for the studied watersheds ranges from $1.2 \%$ in Llanganuco to $11.6 \%$ in Pumapampa.

\subsection{Categorized water sampling and chemical analyses}

Samples were collected in 2008 and 2009 using a synoptic sampling approach in which water samples were taken from a wide variety of sources in a very short time period (Mark and Seltzer, 2003).

Because the samples collected in 2008 highlighted the importance of springs in the hydrology of the glacierized valleys in the Cordillera Blanca (see section 4), we focused the 2009 field campaign on further characterizing this source of water. The 2008 sampling campaign covered the four watersheds extensively (Figure 1), whereas the 2009 sampling campaign focused mainly on the Quilcayhuanca watershed and included a greater sample density than in 2008 (Figure 2). A total of 58 samples were collected in 2008, and 32 were collected in 2009. The local seasonality in precipitation limits the sources of stream water during the dry season to glacial melt water and groundwater (Baraer et al., 2012). The seasonality was confirmed by the absence of observed surface runoff events during the sampling campaigns; thus, direct runoff and soil interflow were not considered as potentially major contributors to the stream flows for this study, which focused on the dry season. 
To facilitate the multi-site field activities as well as the treatment of the results, we grouped the samples into the following sample categories (types):

- MIX, surface water from the main stream, assumed a mix of water sources;

- MELT, melt water from glaciers;

- GWP, groundwater sampled from shallow wells drilled by hand auguring in pampas;

- GW, groundwater pumped from shallow wells drilled by hand auguring in the valley bottoms that are not located in pampas;

- GWS, spring water or surface water from non-glacierized areas; and

- VAL, surface water from the tributaries of the main stream that cannot be classified as groundwater or melt water.

MELT samples were collected from proglacial streams or lakes located downstream of the glacier tongue from drainages with glacierized areas of 50\% or more. Previous studies have shown that the glacier discharge is generally greater than 10 times the groundwater discharge (Baraer et al., 2009). This pattern indicates that the outflow of a catchment that is more than $50 \%$ glacierized is composed of more than $90 \%$ melt water.

The auger holes in the valley floor were two to three meters deep and showed a common sequence of 15 to $20 \mathrm{~cm}$ of organic soils followed by 25 to $60 \mathrm{~cm}$ of organic-rich clay. Several layers of clay, silt, gravel and sand were located below the clay. At several sites, coarser-grained material, such as clasts and boulders, were also found at depth.

Numerous springs (GWS) were observed during the site exploration. For example, within the first five kilometers upslope from the outlet of the Quilcayhuanca watershed, 59 springs were identified on the valley floor, which indicates a density of approximately 44 springs per $\mathrm{km}^{2}$. Most of these springs were located along the lateral slope deposits on the valley bottom. Estimates made during the field survey suggest that the spring discharge ranged from less than one liter per second to 20 liters per second. GWS samples were collected at the spring mouths with the exception of Yanamarey; at Yanamarey, the GWS sample was collected at the outlet of a spring-fed non-glacierized valley located next to the studied watershed that was shown to be representative of the watershed's main source of groundwater in a previous study (Baraer et al., 2009).

The electrical conductivity, $\mathrm{pH}$ and temperature of each sample were measured in the field using a 3500i multimeter (WTW, Germany). All of the water samples collected for hydrochemical analysis were filtered and acidified onsite, kept in completely filled 30 or 60 $\mathrm{ml}$ HDPE bottles and stored at $4^{\circ} \mathrm{C}$ whenever possible. Sampling for isotopic analysis followed a similar protocol except without filtration, and acidification was performed. Major cations $\left(\mathrm{Fe}^{2+}, \mathrm{Fe}^{3+}, \mathrm{Ca}^{2+}, \mathrm{Mg}^{2+}, \mathrm{K}^{+}, \mathrm{Na}^{+}\right)$and the stable isotopes of oxygen and hydrogen $\left(\delta^{18} \mathrm{O}\right.$ and $\left.\delta^{2} \mathrm{H}\right)$ were measured at The Ohio State University using a Dionex DX500 ion chromatography system and a Finnigan MAT Delta plus mass spectrometer coupled to an $\mathrm{HDO}$ water equilibrator, respectively. Major anions $\left(\mathrm{F}^{-}, \mathrm{Cl}^{-}, \mathrm{SO}_{4}{ }^{2-}\right)$ were measured using a 
Dionex DX500 ion chromatography system at McGill University. Bicarbonate concentrations were calculated as the residuals from the charge balance equation.

Cumulative precipitation samples, which were used to establish the local meteoric water line, were collected on a monthly basis in 2006 and 2007 at the office of the Autoridad Nacional del Agua in Huaraz ( 9.52 ${ }^{\circ} \mathrm{S}, ; \sim 77.53^{\circ} \mathrm{W}, 3043$ m.a.s.l.) using a custom-designed totalizing gage following standard procedures (IAEA-WMO, 2011).

Due to an equipment failure in 2009, we were not able to pump water out of the ground (GW and GWP samples) in any watershed except Yanamarey.

\section{4- Hydrological mechanisms and flowpath analysis}

\subsection{Hydrochemical tracers for water source differentiation}

We analyzed the hydrochemical signatures of the potential water sources sampled in all of the watersheds by looking for parameters that depend significantly on the type of water source and are independent of the watershed to use as tracers. We used a multivariate analysis of variance (ANOVA) with two attributes: the water source type (source) and the watershed from which the sample was collected (site) (Table 2). To minimize the influence of subsurface residence time on the potential tracers' values, the tests were performed on relative concentrations of parameters rather than absolute concentrations. A total of 13 parameters were tested as tracers: the nine individual major cation and anion concentrations divided by the sum of the cations or anions respectively; the sum of the monovalent major cations and the sum of the bivalent major cations, both relative to the sum of the cations; the sulfate concentrations divided by the sum of the monovalent major cations; and the sulfate concentrations divided by the sum of the bivalent major cations.

The multivariate ANOVA identified the factors that control the variation of a tracer from one source type to another (Table 2). Of the 13 tested tracers, four showed variations that were significantly $(\alpha=0.05)$ dependent on the source type and were used as indicators of water origin: sulfates, carbonates, iron and the sum of calcium and magnesium. Three other tracers were influenced more by the type of water source than by the sampling site, but at a lower significance $(\alpha=0.1)$. Only one of the tracers, fluorine divided by the sum of the anions, was significantly site dependent.

We verified the ANOVA test results by differentiating between the water sources in each watershed using the four tracers that were shown to be source-dependent with hierarchical clustering. For each watershed, clustering was performed by cross-comparing the dissimilarities (named distances) between the water source samples. Distances between samples were calculated by summing the normalized absolute differences in samples concentration for the four indicators of water origin. Starting with the two elements presenting the lowest calculated distance, samples are paired into binary clusters that are further grouped into larger clusters until a hierarchical cluster tree is obtained. The results are 
represented into a dendrogram (Figure 3) that represents the clustering tree (horizontal axis) and the associated calculated distances (vertical axis). Samples that are connected by a low distance bar can be considered as the most "similar" based on the selected tracers concentrations, those presenting the highest distances can be seen as the less "similar" of the samples. Figure 3 shows that, with the exception of the GW samples, all of the water sources cluster successfully for each site. The differentiation between the MELT samples and the different groundwater sources is unambiguous. The GW samples cluster both with GWS (Quilcayhuanca) and with GWP (Yanamarey), which suggests that the GW source may not form a homogenous group of samples and that a more detailed analysis is needed to clarify the characteristics of these samples.

\section{2-Identifying the main sources of groundwater}

We used scatter plots of the four water source-dependent tracers to investigate the contribution of groundwater to each watershed outflow (Figure 4). Because glaciers form the headwaters of the main streams, we expected to observe mixing points (MIX) that plot away from the melt water locations toward the main contributing groundwater (GW, GWP or GWS) and/or toward tributary plots (VAL). Where only one groundwater type contributes significantly to the watershed outflow, all of the mixing points and tributaries should plot along a mixing line that has the melt water and the contributing groundwater points as extremities.

Because source-dependent tracers were identified from the multivariate ANOVA of only the water source samples, some may not have behaved conservatively at the scale of an entire watershed. When water sources mix with stream water, they may meet hydrochemical conditions that are favorable for changes, such as precipitation, transformation into gas or exchange with other tracers. For example, iron can precipitate when the $\mathrm{pH}$ increases, and carbonates can transform into $\mathrm{CO}_{2}$ when $\mathrm{pH}$ decreases. To avoid misinterpretations of the scatter plots because of non-conservative tracer behavior, we assessed the existence of a mixing line for each tracer in the four watersheds by systematically presenting the MIX/VAL regression line on each scatter diagram. The regression correlation coefficient $\left(\mathrm{R}^{2}\right)$ and the associated $p$-value were then used to determine whether the single mixing line condition was met. When the verification was positive ( $\mathrm{p}$-value $<0.05$ ), the contribution of each water source sample to the watershed outflow was determined by comparing its position on the scatter plot relative to the MIX/VAL regression line's 95\% confidence intervals (Figure 4). Groundwater samples that were outside of the $95 \%$ confidence intervals were considered to not appreciably contribute to the main stream flows. Samples of water sources that plotted within the regression confidence interval and were located at the other extremity of the mixing line from the MELT samples were considered to be major contributors. Where non-conservative tracer behavior was observed, the confidence interval avoided considering a given important contributor as non-contributing. Repeating this analysis for different watersheds and several tracers minimized the risk of randomly misclassifying sources. 
To improve the interpretation of the results, one sample (QVAL4) is not reported on the graphs. This sample has hydrochemical characteristics that are far outside the range of the other samples, possibly because of intense pyrite oxidation (Fortner et al., 2011). The sulfate and magnesium concentrations of QVAL4 are between four and seven times those of the second most concentrated samples. Thus, this sample was excluded because it was hydrochemicaly atypical, and the tributary from which it was sampled was considered to have an insignificant discharge at the watershed scale.

The iron diagrams in Figure 4 show either no significant mixing line (Llanganuco, Yanamarey and Pumapampa) or a poor mixing line (Quilcayhuanca). This pattern is most likely due to the non-conservative behavior described above; thus, this tracer was excluded from the watershed-by-watershed mixing analysis.

At Llanganuco, all of the tracers except iron have well-defined and significant regression lines ( $\mathrm{p}$-value<0.05). However, whereas all of the MELT samples systematically plot within the $95 \%$ confidence interval of the mixing line, none of the GWP samples do, which suggests that the GWP type does not significantly contribute to the watershed discharge at Llanganuco.

At Quilcayhuanca, the mixing lines for all of the tracers are statistically significant (pvalue $<0.05$ ). Of the two GWP samples pumped out of the watershed, one is systematically excluded from the $95 \%$ confidence interval of the regression line and the other is at the limit of the confidence interval (Figure 4). The Quilcayhuanca mixing diagrams also show that the GWS and MELT samples are within the $95 \%$ confidence interval of the mixing line and that all of the MIX and VAL samples plot between these two water sources.

Unlike Quilcayhuanca, Yanamarey has a well-defined mixing line only for the scatter plot of the sum of calcium and magnesium (Figure 4). The small number of mixing or tributary samples used for the regression may explain the two other weak correlations; iron was excluded from this interpretation. The calcium and magnesium diagram shows a nearly perfect alignment of the GWS, MIX and MELT samples, whereas GW and GWP plot away from the $95 \%$ confidence interval. The diagrams of sulfates and bicarbonates show an alignment of the MELT, GWS and MIX samples (red line in Figure 4, Yanamarey sulfate graph). If the regression parameters are calculated using these categories instead of only the MIX samples, the $\mathrm{R}^{2}$ is 0.91 , with a $\mathrm{p}$-value of 0.001 . This finding confirms the strong influence of the MELT and GWS water sources on stream water composition for Yanamarey. The GWP and GW samples plot far from this line, which suggests that these sources did not contribute significantly to the stream water.

The Pumapampa mixing diagrams indicate a more complex situation than in the other watersheds. The MELT sample plots outside the $95 \%$ confidence interval of the calcium plus magnesium mixing line, which suggests that the binary mixing model does not apply to this watershed. Instead, the scatter plots suggest the presence of ternary mixing. The sulfate and bicarbonate diagrams indicate three possible water sources - one MELT and the two GWS 
samples - which form a triangle (in red on the Pumapampa sulfates graph; Figure 4) within which all of the mixing points plot. Such ternary mixing can be considered as two successive binary mixings. First, the melt water would mix with a PGWS2-like groundwater, and then the stream water would mix with PGWS1-like groundwater. This hypothesis is supported by the fact that the two points that plot between PMELT1 and PGWS2, which are the two most upstream MIX points of the watershed, and that the two that plot between the first mixing line and PGWS1 are the two most downstream MIX points. This hypothesis can explain why the MELT sample and one GWS sample plot outside the $95 \%$ confidence interval of the calcium plus magnesium mixing line.

Overall, when the line is well-defined ( $\mathrm{p}$-value<0.05), the MELT samples form one end of the mixing line; thus, the scatter plots consistently represent what is observed at the headwaters of the watersheds (Figure 4). The GWS samples usually plot at the other extremity of the mixing line and likely represent the major groundwater contributor to the watershed discharge during the dry season. Except for one occasion, wherever the mixing line is well defined ( $p$-value<0.05), the GWP samples systematically plot outside the $95 \%$ confidence intervals of the mixing regression. This pattern suggests that the GWP samples have a very limited influence on the stream water concentrations of the studied tracers and indicates that shallow pampa aquifers are likely not major contributors to the stream discharge at the watershed scale. The GW samples are more ambiguous; at Yanamarey, the GW samples do not appear to be a major influence on the stream water chemistry and at Quilcayhuanca their effect is inconclusive. These findings further suggest that the GW samples may not form a unique cluster and that a more in-depth analysis is required to better categorize them.

\subsection{Investigating the contribution of springs to the watershed outflow}

\section{3. a Springs average recharge elevation}

In order to better identify the mechanisms that make springs major watershed outflow contributors, we first used stable isotope values of the springs to estimate recharge area elevations based on empirical altitude/isotopic relationships for the region. This approach assumes an absence of major phase changes or fractionation along the groundwater flowpath (Clark and Fritz, 1997; Blasch and Bryson, 2007) as verified by comparing the $\delta^{2} \mathrm{H} / \delta^{18} \mathrm{O}$ value of each sample collected in 2008 and 2009 with the Local Meteoric Water Line (LMWL). The LMWL, in turn, was calculated using monthly totalized precipitation samples collected in the city of Huaraz (Figure 1) between 2006 and 2007. The monthly precipitation volumes and the associated $\delta^{18} \mathrm{O}$ values of the precipitation samples exhibit similar variation patterns (Figure 5). This covariation between the two parameters is confirmed by a coefficient of determination $\mathrm{R}^{2}$ of 0.72 and an associated p-value of 0.0007 and corroborate the presence of an amount effect (Vuille et al., 2003; Vimeux et al., 2005; Risi et al., 2008).

The LMWL (Figure 6) is defined by the regression equation $\delta^{2} \mathrm{H}=7.5 \delta^{18} \mathrm{O}+0.146$ and by an $\mathrm{R}^{2}$ of 0.94 and an associated $\mathrm{p}$-value of less than 0.0001 . The $\delta^{18} \mathrm{O}$ and $\delta^{2} \mathrm{H}$ values for the 58 samples collected in 2008 range from $-13.45 \%$ o to $-16.81 \%$ and $-104.2 \%$ o to $-128.5 \%$, 
respectively, and the 38 samples collected in 2009 range from $-14.38 \%$ to $-19 \%$ and $147.1 \%$ o to $-110.12 \%$, respectively. The slightly lower $\delta^{18} \mathrm{O}$ and $\delta^{2} \mathrm{H}$ values in 2009

compared to 2008 suggest a slight inter-annual difference in the stable isotopic characteristics of the precipitation between the two years of sampling. This variation may be El NiñoSouthern Oscillation (ENSO) related (Vuille and Werner, 2005) as a moderate La Nina was measured during the 2007-2008 rainy season and a weak La Niña in 2008-2009 (Peterson et al., 2009; Arndt et al., 2010). A comparison of the locations of the 2008 and 2009 samples to the LWML on the $\delta$-diagram (Figure 6) shows that all of the samples plot well within the LWML's 95\% confidence interval and that no distinctive trends exist between the precipitation and the samples collected in the watersheds. These results indicate that little to no post-precipitation fractionation had affected the $\delta^{18} \mathrm{O}$ and $\delta^{2} \mathrm{H}$ values in the tested water at the time of sampling, confirming observations from other studies showing that sublimation and evaporation have little impact on the isotopic values of ice (Stichler et al., 2001; Wassenaar et al., 2011) and groundwater (Longinelli et al., 2008; Parisi et al., 2011).

We then used the relationship between altitude and isotopic value to estimate the elevation of the spring recharge area by comparing the position of the spring water isotope value to the line of the aquifer's minimum average recharge elevation for the samples collected in 2008 (Figure 7). This line is determined using the pampa shallow aquifer samples (GWP) as reference points and published $\delta^{18} \mathrm{O}$ and $\delta^{2} \mathrm{H}$ lapse rates measured in the tropical Andes.

Because the GWP recharge area cannot be located at a lower elevation than the sampling point, and because shallow groundwater often mimics the altitude effect (McKenzie et al., 2010), the average GWP (average GWP isotope value plotted against the mean GWP sampling elevation) forms one point on the line of minimum mean recharge elevation. In order to prevent over estimations of the spring recharge elevation, we applied the lowest of published values for the slope of the lines (Table 3). The resulting lines are defined by the following equations:

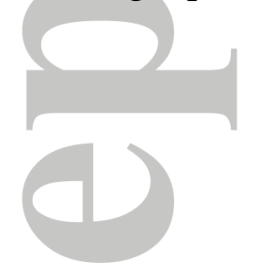

$$
\begin{aligned}
& \delta^{18} O=-0.0024 * z-4.9 \\
& \delta^{2} H=-0.017 * z-42.2
\end{aligned}
$$

where $z$ represents the mean recharge elevation. For each isotope, we compared the resulting line with the GWP-MELT regression lines to validate that the method would not lead to over estimation of the spring recharge elevation. For the regression lines, we used the terminus elevation plus one quarter of the glaciers elevation range to calculate the MELT samples reference elevation. This definition is preferred to the average elevation (Ofterdinger et al., 2004) because tropical glaciers are characterized by greater accumulation area ratios than are typical of temperate glaciers (Kaser and Ostmaston, 2002). Figure 7 shows that the lines of minimum mean recharge elevation have a more pronounced slope than the GWP-MELT regression lines. This indicates a tendency for underestimation of the samples representative elevation, validating that the risk of overestimating the aquifer average elevation is low. 
The relative recharge elevation of the GWS aquifer is estimated using the sampled isotopic values (Table 4), assuming that the sampled perennial springs have isotopic signatures that represent the yearly average of the precipitation that feeds them. Because the amount effect (presented above) causes the rainy months to determine the mean annual $\delta^{18} \mathrm{O}$ and $\delta^{2} \mathrm{H}$ values of the precipitation (Gonfiantini et al., 2001), deviations from this assumption would lead to higher isotopic values in the spring water than the yearly average. This conjecture suggests that using the isotopic values of the spring water likely provides a conservative estimate of the recharge elevation rather than overestimating it.

Figure 7 shows that the GWS samples all plot beneath the line of minimum average aquifer recharge elevation for both $\delta^{18} \mathrm{O}$ and $\delta^{2} \mathrm{H}$. Despite the limited number of samples, the use of a conservative reference line indicates that the recharge area of the springs is located at elevations higher than the sampling points. The vertical distances between the springs and their average recharge elevations are estimated using Equations (1) and (2). The results (Table 4) show relatively high consistency between the $\delta^{18} \mathrm{O}$-based estimates and the $\delta^{2} \mathrm{H}$ based estimates. The method indicates that the minimum mean elevation of the recharge areas is located approximately $200 \mathrm{~m}$ to $600 \mathrm{~m}$ above the sampling points.

\section{3.b Flowpath and water origin}

Investigating for flowpath and water origins for springs was realized by comparing the hydrochemical and isotopic characteristics of the springs to melt water and stream water for samples and observations collected in 2009. The hydrochemical signatures of the samples were examined using a hierarchical clustering analysis, whereas their isotopic characteristics were used to assess the relative elevations of the recharge areas.

Of the 11 springs sampled in 2009 (Fig. 2), nine were located at the base of lateral talus slopes. The two other springs, QGWS7 and QGWS4, were located approximately halfway between the valley wall and the river bed. . The QGWS7 was artesian; water rose up to the pampa surface from a vertical hole that was estimated to be more than 1.5 meters deep. Spring QGWS4 was located at the bottom of a deposit that extends across the valley floor and is likely to be at the base of the remains of an end moraine or an old avalanche cone.

We performed a hierarchical clustering (see method description at point 4.1) using the same tracers as in the 2008 samples (Figure 8). In addition to the MELT and GWS samples, we included five other samples of known origin in the analysis to evaluate the method's performance. Two samples, QVAL3 and QVAL7, were streams that originated from nonglacierized sub-watersheds, and three others (QVAL 1, QVAL5 and QMIX3) were streams at least partly composed of melt water.

The results show that these five test samples cluster well with the other samples of similar origin. QVAL3 and QVAL7 plot within a group composed of most of the sampled springs, and the three samples that are at least partly composed of melt water plot next to the MELT 
samples on the dendrogram. This test allows the first group of springs to be defined as the precipitation water cluster (blue lines in Figure 8) and the samples located next to the MELT samples to be defined as the melt water group (red lines).

The dendrogram (Figure 8) also shows the influence of geospatial proximity on clustering. For example, QGWS11 and QGWS10, which form the cluster of lowest calculated distance, are also the spatially closest springs that were sampled. A similar situation occurs with QGWS8 and QGWS9 which have the second lowest distance. Such similarities in hydrochemical characteristics are possibly due to springs that serve as different outlets of the same aquifer. The physical proximity is not the only factor that affects the hydrochemical proprieties of the springs. Clusters formed by springs that are located far from each other, such as QGWS3 and QGWS6, show that most of the springs in the valley share several hydrochemical characteristics that make them distinct from the melt water samples. These differences confirm the observations of the 2008 samples. Samples QGWS7 and QGWS4, which were collected from springs that are not located in the lateral deposits at the bottom of the valley, do not form a specific cluster but rather are grouped with the other precipitationfed springs. Sample QGWS7 is the only artesian-like spring that was observed during the 2009 dry season sampling campaign. This spring clusters with two nearby springs (GWS8 and GWS9). Thus, sample QGWS7 is part of a GWS group that was clearly hydrologically separate from the water pumped from pampa shallow aquifers (GWP) in the 2008 samples. The QGWS7 water therefore did not originate from the shallow pampa aquifer but rather from the lateral deposits. The relative location of the springs in the valley (Figure 2) supports the assumption that water flows beneath the valley floor from the side of the valley to the middle of the pampa and is confined by the low permeability glaciolacustrine pampa sediments. QGWS4 was not sampled from a lateral deposit but instead flowed from frontal deposits. The presence of QGWS4 within the precipitation cluster does not make it distinct from the springs that flow from lateral deposits. With the exception of the QGWS2 sample, all of the GWS samples plot within the precipitation cluster. The QGWS2 and QVAL1 samples plot within the melt water group and form the cluster of lowest calculated distance within the melt water cluster. This strong relationship suggests that QGWS2 is at least partially fed by melt water.

The plot of $\delta^{2} \mathrm{H}$ versus $\delta^{18} \mathrm{O}$ (Figure 9) confirms that the QGWS2 water is distinct from the other GWS samples. QGWS2 has the lowest $\delta^{18} \mathrm{O}$ and $\delta^{2} \mathrm{H}$ values, which are even lower than those of the MELT samples. The relation that ties recharge elevation with the $\delta^{2} \mathrm{H}$ and $\delta^{18} \mathrm{O}$ values of the samples that was established using the 2008 samples (Figure 7) suggests that QGWS2 is fed by water that originates from the highest part of the surrounding peaks. Field observations revealed the presence of small glacial remains or dead ice (less than 100 meters long) on the summits above the spring. The hydrochemical and isotopic characteristics of QGWS2 are best explained by melt water from this ice at least partially feeding this spring. Figure 9 also shows that the samples and the LMWL exhibit similar trends. The spring samples plot slightly underneath the LMWL, which may indicate an inter-annual modification of the isotopic signal in the precipitation (Gonfiantini et al., 2001). The influence of geospatial proximity observed for most of the spring samples on the cluster 
analysis is confirmed by the plot. QGWS10 and QGWS 11 have very similar $\delta^{2} \mathrm{H}$ and $\delta^{18} \mathrm{O}$ values, as do QGWS8 and QGWS9. The artesian spring QGWS7 has slightly lower $\delta^{2} \mathrm{H}$ and $\delta^{18} \mathrm{O}$ values than QGWS8 and QGWS9, which are the two nearby springs with which it was grouped in the cluster analysis. This difference could be explained by the average elevation of the recharge area of the artesian spring being slightly higher than that of springs QGWS8 and QGWS9.

\section{5- Quantifying the contribution of groundwater to dry season watershed outflow}

The contribution of groundwater to stream flow during the dry season is quantified using the hydrochemical basin characterization method (HBCM), which is a multi-component distributed hydrochemical mixing model. This method was chosen for its ability to produce reliable results in ungauged, difficult to access environments (Baraer et al., 2009). Because HBCM requires a synoptic sampling approach in which all samples are collected within a very limited amount of time, it provides a geospatial snapshot of the contributions of different sources of water across the watershed. The geospatial coverage of HBCM is based on dividing the watershed into nested interconnected sub-watersheds called cells, as depicted for the 2008 Quilcayhuanca campaign in Figure 10. The outlets of cells, where rivers join, are contributors to the subsequent downstream cell. The number of cells is mainly a function of the basin complexity and the sampling density and ranges from three cells in Yanamarey to seven in Llanganuco. Partial overlaps of the cells are used to accumulate component contributions for the entire watershed. This process is performed by considering nonglacierized catchments to be completely fed by groundwater, an assumption supported by the near absence of precipitation during the dry season (Baraer et al., 2012). MELT samples are defined as being completely fed by melt water. Water that originates in other catchments is considered to be unclassified. The contributions of unclassified catchments are not accounted for in the total water budget of the watershed. As a result, the calculated contributions of groundwater and melt water apply to the entire study watershed area minus the areas that are covered by the unclassified catchments. These calculated sub-areas to which groundwater and melt water contributions apply are called the "study areas" in the rest of the document, and they are identified by the study watershed name appended with an '*'; their characteristics are presented in Table 5. The Yanamarey* area is the same as the true Yanamarey area, and the Llanganuco* area is only 5\% smaller than the actual Llanganuco area. Pumapampa* shows the greatest reduction in area. Its study area represents $33 \%$ of the watershed area. The Quilcayhuanca* study area represents $82 \%$ of the actual watershed area.

Each HBCM cell gathers surface water sampled within its spatial limits plus a groundwater component that is selected from the sampled sources. The cell areas and glacier coverage are calculated using ARC HYDRO (Maidment, 2002) with 1:100,000 digitized contour lines. The relative contribution of each identified component to the cell outflow is estimated using an over-parameterized set of mass balance equations. Assuming a well-mixed system, $m$ mass balance equations are defined for each cell using the following format: 


$$
C_{\text {tot }_{j}}=\frac{\sum_{i=1}^{n}\left(C_{i_{j}} \cdot Q_{i}\right)+\varepsilon_{j}}{Q_{t o t}}
$$

where $j$ represents a natural tracer; $i$ is a component of the cell outflow, such as a tributary or a groundwater source; $C_{\text {tot }_{j}}$ and $C_{i_{j}}$ represent the relative concentration or proportion of tracer $j$ at the cell outlet and in component $i$, respectively; and $n$ is the total number of possible components of cell outflow considered in the studied cell. Over-parameterization of the set of mass balance equations requires that $m$ greater than $n . Q_{t o t}$ and $Q_{i}$ correspond to the total discharge at the cell outlet and the contribution of the component $i$, respectively, and $\varepsilon_{j}$, which ideally is close to zero, corresponds to the accumulation of inaccuracies, uncertainties, errors and approximations that can occur during the sampling, handling and analysis of tracer $j$.

The tracers used in the mass balance equations are selected from all of the measured parameters (see Section 3 for a description of the measurements). Compliance with the three following requirements is checked for each cell and each tracer:

1. a tracer measured in a cell outflow cannot have a value outside the range defined by the possible contributors;

2. the tracer value at the cell outflow and at least one contributor must be greater than the detection limit of the analytical methods; and

3. it should be a minimum 5\% difference between the extreme contributor tracer values.

A noncompliance with any of these requirements leads to the rejection of the tracer for the studied cell.

For each cell, all possible combinations of $m$ tracers are tested through different HBCM runs. An HBCM run solves for the components of unknown relative discharge, for a combination of $\mathrm{m}$ selected tracers, by minimizing a cost function that is defined as the cumulative residual error (the sum of $\varepsilon_{j}$ ). HBCM uses the quasi-Monte Carlo approach (James, 1980) to calculate the cost function for random points sampled over the feasible region. The feasible region is determined using a water balance constraint that requires that the sum of the relative components of discharge be equal to one plus or minus half a percent. For each run, more than 100,000 constrained relative discharge combinations are applied to localize the cost function's global minimum. To minimize the risk of picking a local minimum, the 20 lowest cumulative residuals are considered to estimate the best fitting relative contribution of the components to the cell outflow. In the case of non-convergent results, attractive regions are resampled to separate local minima from the global minimum (Arora et al., 1995). For each run, the HBCM output is therefore given in the form of an array of the best fitting relative discharges that form the 20 best converging optimization results. The HBCM results with a range of less than $1 \%$ are considered unique values. HBCM results for a given cell are selected among the different runs that were conducted. The combination of tracers that provide the overall lowest cumulative residue is considered to be the optimal solution. The 
range of watershed-wide groundwater contributions was compiled from the results of the individual cells by using the lowest bound of each cell to obtain the lowest watershed-wide estimate and the highest bound of each cell to obtain the highest watershed-wide estimate.

The relative discharges were converted to absolute discharges using stream discharge measurements made at the lowest section of each study watershed using the cross-sectional averaging technique (Mark and Seltzer, 2003). The stream water velocity was measured simultaneously with the sampling with a mechanical flow meter (Model FP101, Global Waters Inc.). This method is well suited to the logistical constraints that characterize the high valleys of the tropical Andes but has an associated error of $+/-20 \%$ and a tendency to overestimate the values (Shrestha and Simonovic, 2010). At Quilcayhuanca, seven additional stream flow measurements were made across the valley using the same technique to evaluate the performance of HBCM in estimating ungauged stream discharge.

The HBCM results for individual cells are shown in Figure 11. HBCM was able to provide estimates of the contribution of groundwater within a 5\% window for all of the cells except one in Pumapampa. The estimation range was notably higher in Llanganuco and Pumapampa than in Yanamarey and Quilcayhuanca, which indicates differences in the adequacy of the sampling plans and/or a smaller difference in the hydrochemical signatures of the different sources. This lack of a difference in the hydrochemical signature between samples was observed several times in Llanganuco and is responsible for the unsuccessful HBCM characterization of the most downstream cell of that watershed.

Figure 12 presents a comparison of the HBCM discharge estimation to field measurements. The discharges are associated with error bars of $+/-20 \%$, which represents the uncertainty in the stream gauging method (Shrestha and Simonovic, 2010), and horizontal error bars that represent the HBCM estimation range. The plot shows a very high correlation $\left(\mathrm{R}^{2}=0.99\right)$ between the measured and the HBCM-estimated discharges with a very high statistical significance ( $\mathrm{p}$-value $<10^{-6}$ ). The equation of the regression line expresses a tendency for a systematic overestimation of the measured discharge, which is consistent with the conclusions of Shrestha (Shrestha and Simonovic). Figure 12 shows that the method is applicable for this study and that its degree of uncertainly is compatible with the objective of evaluating the extent to which groundwater contributes to the dry season discharge in glacierized valleys of the Cordillera Blanca.

At Yanamarey* and Pumapampa*, the contributions of groundwater to the outflow are greater than those of melt water (Table 5). The opposite pattern was observed at Llanganuco*, and an overlap in the prediction ranges made such a comparison inconclusive for Quilcayhuanca*. The average specific groundwater discharge for the study areas varied from $0.36 \mathrm{~mm} . \mathrm{d}^{-1}$ at Quilcayhuanca* to $0.74 \mathrm{~mm} . \mathrm{d}^{-1}$ at Llanganuco*. The estimate from Pumapampa* exhibited the highest uncertainty $\left(+/-0.11 \mathrm{~mm} \cdot \mathrm{d}^{-1}\right)$. We note that none of the valleys had a groundwater-specific discharge of less than $0.35 \mathrm{~mm} \cdot \mathrm{d}^{-1}$. 
To evaluate the variability of the groundwater contribution at the scale of the Cordillera Blanca, the relative groundwater contribution of each study area was plotted against its percentage of glacierized area (Figure 13). The relationship between these two parameters was assessed through a nonlinear regression performed with the following two-component mixing model (Baraer et al., 2009):

$$
G W=100 \times \frac{a\left(100-A_{g l}\right)}{A_{g l}+a\left(100-A_{g l}\right)}(4)
$$

where $G W$ represents the percentage of groundwater contribution, $A_{g l}$ represents the percentage of glacierized area and $a$ is a dimensionless constant. The regression uses the four study area points and the two boundary limits, which are $0 \%$ and $100 \%$ glacierized areas (Figure 13). The results show a good fit between the estimated relative contributions of groundwater and the mixing model outputs $\left(\mathrm{R}^{2}=0.98\right.$, $\mathrm{p}$-value $\left.=0.0007\right)$.

Despite the limited number of points used for the regression, the prediction intervals are narrow enough to confirm that a nonlinear relationship bounds the relative contribution of groundwater to the watershed outflow and the percentage of glacierized area across the Cordillera Blanca. The shape of the regression line clearly illustrates the difference in specific discharge between glacierized and non-glacierized areas. On average, a glacierized area contributes more to stream outflows than a non-glacierized area of similar size. The lowest 95\% confidence interval line indicates that during the dry season of 2008 in the Cordillera Blanca, watersheds with less than $45 \%$ glacierized area likely contained substantial amounts of groundwater in their outflows and that those with less than $8 \%$ glacierized area had more groundwater than melt water in their outflows.

\section{6- Discussion}

The different facets of this study provide results describing the hydrology of glacierized valleys in the Cordillera Blanca that both confirm and complement each other.

Field campaigns and sampling activities allowed the identification of three potential types of groundwater: spring water, water from the pampa shallow aquifer and water from non-pampa shallow aquifers. The shallow aquifers contained a similar sequence of soil layers that includes low permeability clay and silt layers.

The results from the use of tracers that were shown to be water source dependent and independent of the study site in a qualitative analysis of samples collected in 2008 provide key indications of the hydrology of the studied valleys: 
- Samples collected from springs and pumped from shallow pampa aquifers have distinct hydrochemical characteristics, which confirm that these two water types are different.

- The shallow pampa groundwater appears to have very little influence on the hydrochemical characteristics of the stream water, which indicates that these shallow glaciolacustrine systems are likely a minor component of the net flux of water to the main valley streams.

- Aquifers that feed the springs contribute significantly to the overall basin discharge. This hydrochemistry-based result is consistent with field observations that report a high density of springs in the Quilcayhuanca Valley (44 springs $/ \mathrm{km}^{2}$ ).

- Most of the springs were sampled at the bottom of talus deposits.

The analysis of the stable isotope signatures of the 2008 water samples suggests that the springs sampled at the bottom of a talus slope are fed by precipitation that flows down from elevations above the springs and even higher than the top portion of the deposit from which they originate.

The quantitative evaluation of the contribution of groundwater to the hydrologic systems performed on the 2008 samples using HBCM suggests that significant groundwater volumes are present in the four studied watersheds. Despite the differences in their attributes (e.g., location, geology, glacial cover), all of the valleys capture precipitation during the wet season and store it in a hydrogeological system that releases it year-round. Important differences exist in the relative contributions of groundwater among the watersheds, but these differences are at least partly explained by the differences in the glacierized areas. This aspect of the study confirms that groundwater, which was already proven to be a key component in alpine catchments (Rademacher et al., 2001; Clow et al., 2003; Hood et al., 2006; Williams et al., 2006; Langston et al., 2011), plays a key role in the dry season hydrology in the glacierized valleys of the Cordillera Blanca.

The 2009 sampling focused on the springs because they were shown to play a key role in the contribution of groundwater to the watershed outflows in the 2008 dry season. A field survey showed that springs that flow out of the lateral deposits are the most common, but a few exceptions were found. One artesian spring (QGWS7) was found a few tens of meters from the lateral deposits in the pampa, and one spring (QGWS4) was discovered at the bottom of a frontal deposit that may be a frontal moraine or a massive landslide that crossed the entire valley.

The hydrochemical analysis of the samples collected in 2009 revealed the following:

- Water from the artesian spring (QGWS7) likely has a similar source as the water sampled at nearby lateral springs, which suggests a common source of geologic strata.

- The results were less conclusive for the spring flowing from a frontal deposit (QGWS4) but indicate that the water that flows from it has a similar hydrochemical 
signature to those flowing from the lateral springs. However, there is no clear link to any of these springs in particular.

At least one of the lateral springs (QGWS2) had a melt water-like signature, which indicates a partial or complete connection with melting ice.

Finally, the isotopic signatures of the spring samples mainly confirm that QGWS2 is fed by water originating from high elevations, such as ice melt water.

These results can be synthesized to depict the dry season hydrological processes using a conceptual model for the Cordillera Blanca proglacial valley (Figure 14). The model presents the valley side deposits/talus as key hydrogeological features for groundwater recharge. The recharge of these lateral deposits can have three sources: direct precipitation falling on the surface of the deposit, recent precipitation that flows from areas of higher elevation and melt water from glaciers or dead ice. The top layer of the pampas is considered to be an area with a small contribution to the surface water at the watershed scale. Water flows out of the lateral deposits through springs that are located at the interface between the lateral or frontal deposits and the surface of the pampas or from artesian springs that flow through the pampa surface. The latter mechanism implies the transfer of water between the lateral deposits and the ground deposits. Water that flows through the ground deposits beneath the pampa floor is confined by the pampa's surface layer. Because it is over-pressurized, this water escapes through preferential pathways in the pampa's surface layer. This sequence allows the eventual transfer of water from the ground deposits into the river bed. Even if this type of transfer occurs, it would not have been detected using the investigation method used in this study and is not described in Figure 14.

The model requires that water that transits through the lateral deposits has a retention time that is long enough to maintain lateral springs throughout the dry season. Because a long retention time is unlikely to occur in the coarse deposits of the talus surfaces, other mechanisms must be operating. Among the numerous possibilities, we cite three realistic hypotheses that, alone or associated with other phenomena, may explain the long retention time:

- The presence of different types of deposits, such as the remains of lateral moraines, that buffer some of the water collected at the talus surface (e.g. Clow et al. (2003); (Sass et al., 2006)).

- The existence of flow through fractured bedrock beneath the lateral deposits (e.g., Langston et al. (2011)) that can be enhanced by bedrock depressions and lateral flow along the interface between the deposits and the bedrock (Graham and McDonnell, 2010; Graham et al., 2010).

- Re-sedimentation of the talus slope, which causes fine particles to be flushed from the top to the bottom of the talus and makes the talus highly permeable at the top and poorly permeable at the bottom (e.g., Ballantyne (2002)). 
However, further studies are needed to verify these hypotheses in the context of the tropical Andes.

Presenting the valley side deposits as key hydrogeological features at the scale of mountainous catchments is not new. Several studies conducted in other alpine environments (Roy and Hayashi, 2009; Langston et al., 2011; Muir et al., 2011) have demonstrated the key hydrological role played by lateral deposits and talus. For instance, McClymont et al. (2011) provided evidence of the role of the talus/meadow interface in the proglacial hydrology of the Rocky Mountains of Canada, and Clow et al. (2003) demonstrated that talus slopes are the primary groundwater reservoir in an Alpine catchment in the Rocky Mountains of Colorado. However, the present model confirms that these geological features are also a key element in the context of the tropical Andean hydrology. The model describes the recharge and discharge pathways of these aquifers based on hydrochemical evidence and field observations. Finally, the model proposes the first comprehensive description of the dry season hydrology of glacierized watersheds in the Cordillera Blanca.

\section{7- Conclusions}

The hydrochemical and isotopic signatures of several water source types were used to study the hydrogeological characteristics of four glaciated valleys in the Cordillera Blanca, Peru. The methods we tested were shown to be specifically adapted for proglacial systems. However, assuming that the necessary tracer characteristics exist, they are potentially transferable to other watersheds. Despite the uncertainty in the results, the methods are particularly useful in remote ungauged regions where intensive and expensive physical hydrologic methods are not practical.

Our results provide new perspectives on the regional proglacial hydrology. Three findings are of particular interest for both general alpine hydrology and for Andean water resources:

- Groundwater is a major hydrologic contributor during the dry season in the glacierized watersheds of the Cordillera Blanca. Our estimates of the contribution of groundwater in four watersheds of the Cordillera Blanca range between 0.36 and $0.74 \mathrm{~mm} . \mathrm{d}^{-1}$ for the dry season of 2008 representing between $24 \%$ and $80 \%$ of the study areas outflow.

- In the proglacial valleys of the Cordillera Blanca, talus deposits are a key component of the hydrological system. These deposits both collect water that flows from higher elevations along the side walls of the valleys and release it at lower elevations with a time lag that is long enough to sustain groundwater flow during the dry season. Talus groundwater is released from springs located at the bottom of the deposits and into unconsolidated aquifers within the valley floor. Unlike the hydrological role of the talus, shallow pampa aquifers do not appear to contribute substantially to the dry season watershed outflow. 
- $\quad$ Many springs are recharged by precipitation, but some are also fed by melt water. These melt water fed springs are likely to be more vulnerable to climate changes as they may become ephemeral when the ice supply disappears.

Using our hydrochemical analysis as a guide, we proposed a conceptual hydrologic model for the dry season hydrology of the glacierized watersheds in the Cordillera Blanca. We consider this model to be a preliminary schematic description of the dry season hydrology of the glacierized watersheds of the Cordillera Blanca that will be updated by future research. This preliminary model leaves several hydrological phenomena unexplained in the context of the tropical Andes, such as the capacity of the talus to retain captured water long enough to produce perennial springs. The talus surface, which is composed primarily of porous paraglacial deposits, should theoretically release the captured water rapidly unless fracture flow, layers of other deposits or re-sedimentation of the deposits is involved. A more systematic quantification of the melt groundwater sources, which is not provided by this study, would be an important step forward in assessing the impact of glacial retreat on local water resources.

\section{8- Acknowledgements}

We are grateful for the funding provided by the National Science Foundation (BCS0752175); the Geochemistry and Geodynamics Research Centre (GEOTOP) of Quebec; the Natural Science and Engineering Research Council (NSERC) of Canada; McGill University; and The Ohio State University's Climate, Water and Carbon Program. The authors thank the École Superieure de Technologie of Canada for its support in finalizing the research under the best possible conditions.

\section{9- References:}

Arndt DS, Baringer MO, Johnson MR, Alexander LV, Diamond HJ, Fogt RL, Levy JM, Richter-Menge J, Thorne PW, Vincent LA, Watkins AB, Willett KM. 2010. State of the climate in 2009. Bulletin of the American Meteorological Society, 91: S1-S218.

Arora JS, Elwakeil OA, Chahande AI, Hsieh CC. 1995. Global optimization methods for engineering applications: A review. Structural Optimization, 9: 137-159.

Ballantyne CK. 2002. Paraglacial geomorphology. Quaternary Science Reviews, 21: 19352017.

Baraer M, Mark BG, McKenzie JM, Condom T, Bury J, Huh K, Portocarrero C, Gomez J, Rathay S. 2012. Glacier recession and water resources in Peru's Cordillera Blanca. Journal of Glaciology, 58: 134-150.

Baraer M, McKenzie JM, Mark BG, Bury J, Palmer S. 2009. Characterizing contributions of glacier melt and groundwater during the dry season in a poorly gauged catchment of the Cordillera Blanca (Peru). Advances in Geosciences 22: 41-49.

Barbieri M, Boschetti T, Petitta M, Tallini M. 2005. Stable isotope (2H, $18 \mathrm{O}$ and $87 \mathrm{Sr} / 86 \mathrm{Sr})$ and hydrochemistry monitoring for groundwater hydrodynamics analysis in a karst aquifer (Gran Sasso, Central Italy). Applied Geochemistry, 20: 2063-2081. 
Benn D, Evans D. 1998. Glaciers and glaciation. Arnold, London.

Blasch KW, Bryson JR. 2007. Distinguishing sources of ground water recharge by using $\delta 2 \mathrm{H}$ and $\delta 180$. Ground Water, 45: 294-308.

Bradley RS, Vuille M, Diaz HF, Vergara W. 2006. Threats to water supplies in the tropical Andes. Science, 312: 1755-1756.

Burns P, Nolin A. 2014. Using atmospherically-corrected Landsat imagery to measure glacier area change in the Cordillera Blanca, Peru from 1987 to 2010. Remote Sensing of Environment, 140: 165-178.

Bury J, Mark B, McKenzie J, French A, Baraer M, Huh K, Zapata Luyo M, Gómez López R. 2011. Glacier recession and human vulnerability in the Yanamarey watershed of the Cordillera Blanca, Peru. Climatic Change, 105: 179-206.

Buytaert W, Deckers J, Wyseure G. 2006. Description and classification of nonallophanic Andosols in south Ecuadorian alpine grasslands (p ̃ $;$ ramo). Geomorphology, 73 : 207-221.

Caballero Y, Jomelli V, Chevallier P, Ribstein P. 2002. Hydrological characteristics of slope deposits in high tropical mountains (Cordillera Real, Bolivia). Catena, 47: 101-116.

Chevalier P, Pouyaud B, Suarez W. 2004. Climate Change impact on the water resources from the mountains in Peru. OECD conference: "Global Forum on Sustainable Development: Development and Climate Change". November 2004, Paris, France.

Clark ID, Fritz P. 1997. Environmental Isotopes in Hydrogeology. Lewis Publishers.

Clow DW, Schrott L, Webb R, Campbell DH, Torizzo A, Dornblaser M. 2003. Ground Water Occurrence and Contributions to Streamflow in an Alpine Catchment, Colorado Front Range. Ground Water, 41: 937-950.

Coudrain A, Francou B, Kundzewicz ZW. 2005. Glacier shrinkage in the Andes and consequences for water resources. Hydrological Sciences Journal, 50: 925-932.

Crossman J, Bradley C, Boomer I, Milner A. 2011. Water flow dynamics of groundwater-fed streams and their ecological significance in a glacierized catchment. Arctic, Antarctic, and Alpine Research, 43: 364-379.

Drever. 2005. Surface and Ground Water, Weathering, and Soils. Eslevier-Pergamon Oxford. Fortner SK, Mark BG, McKenzie JM, Bury J, Trierweiler A, Baraer M, Burns PJ, Munk L. 2011. Elevated stream trace and minor element concentrations in the foreland of receding tropical glaciers. Applied Geochemistry, 26: 1792-1801.

Francou B. 1989. Régime thermique des sols et rôle du gel dans la dynamique des versants d'un milieu subéquatorial d'altitude : les Andes centrales du Pérou. Géographie physique et Quaternaire, 43: 97-112.

Garcia M, Villalba F, Araguas Araguas L, Rozanski K. 1998. The role of atmospheric circulation patterns in controlling the regional distribution of stable isotope contents in precipitation: Preliminary results from two transects in the Ecuadorian Andes. Isotope techniques in the study of environmental change. Proceedings of a symposium, Vienna, April 1997: 127-140.

Gat JG. 2010. Isotope Hydrology, a study of the water cycle. Imperial College Press.

Georges C. 2004. 20th-century glacier fluctuations in the tropical Cordillera Blanca, Peru. Arctic Antarctic and Alpine Research, 36: 100-107.

Girard S. 2005. Paramos, strategic spaces for managing water resources in the northern Andes: The Rio Ambato basin (Ecuador). Mappemonde, 78.

Goldthwait RP, Matsch CL. 1989. Genetic classification of glacigenic deposits. A. Balkema. Gonfiantini R, Roche M-A, Olivry J-C, Fontes J-C, Zuppi GM. 2001. The altitude effect on the isotopic composition of tropical rains. Chemical Geology, 181: 147-167. 
Graham CB, McDonnell JJ. 2010. Hillslope threshold response to rainfall: (2) Development and use of a macroscale model. Journal of Hydrology, 393: 77-93.

Graham CB, Woods RA, McDonnell JJ. 2010. Hillslope threshold response to rainfall: (1) A field based forensic approach. Journal of Hydrology, 393: 65-76.

Hood JL, Roy JW, Hayashi M. 2006. Importance of groundwater in the water balance of an alpine headwater lake. Geophysical Research Letters, 33. DOI: 10.1029/2006GL026611.

IAEA-WMO. 2011. Programme on Isotopic Composition of Precipitation: Global Network of Isotopes in Precipitation (GNIP), Technical Procedure for Sampling. IAEA.

James F. 1980. Monte Carlo theory and practice. Reports on Progress in Physics, 43: 11451189.

Jeelani G, Bhat NA, Shivanna K. 2010. Use of Oxygen eighteen tracer to identify stream and spring origins of a mountainous catchment: A case study from Liddar watershed, Western Himalaya, India. Journal of Hydrology, 393: 257-264.

Juen I, Kaser G, Georges C. 2007. Modelling observed and future runoff from a glacierized tropical catchment (Cordillera Blanca, Peru). Global and Planetary Change, 59: 37-48.

Kaser G, Georges C. 1999. On the mass balance of low latitude glaciers with particular consideration of the Peruvian Cordillera Blanca. Geografiska Annaler Series, aPhysical Geography, 81A: 643-651.

Kaser G, Ostmaston H. 2002. Tropical Glaciers. Cambridge University press.

Knutsson G. 2008. Hydrogeology in the Nordic countries. Episodes, 31: 148-154.

Kohfahl C, Sprenger C, Herrera JB, Meyer H, Chacon FF, Pekdeger A. 2008. Recharge sources and hydrogeochemical evolution of groundwater in semiarid and karstic environments: A field study in the Granada Basin (Southern Spain). Applied Geochemistry, 23: 846-862.

Kortelainen N. 2011. Isotope tracing in groundwater applications. Geological Survey of Finland, special paper 49: 279-284.

La Frenierre J, Mark BG. 2014. A review of methods for estimating the contribution of glacial meltwater to total watershed discharge. Progress in Physical Geography. DOI: 101177/0309133313516161.

Langmuir D. 1997. Aqueous Environmental Geochemistry. Prentice-Hall.

Langston G, Bentley LR, Hayashi M, McClymont A, Pidlisecky A. 2011. Internal structure and hydrological functions of an alpine proglacial moraine. Hydrological Processes, 25: 2967-2982.

Longinelli A, Stenni B, Genoni L, Flora O, Defrancesco C, Pellegrini G. 2008. A stable isotope study of the Garda lake, northern Italy: Its hydrological balance. Journal of Hydrology, 360: 103-116.

Maidment DR. 2002. Arc Hydro: GIS for Water Resources. ESRI Press.

Mark BG, Bury J, McKenzie JM, French A, Baraer M. 2010. Climate change and tropical Andean Glacier recession: Evaluating hydrologic changes and livelihood vulnerability in the Cordillera Blanca, Peru. Annals of the Association of American Geographers, 100: 794-805.

Mark BG, McKenzie JM. 2007. Tracing increasing tropical Andean glacier melt with stable isotopes in water. Environmental Science \& Technology, 41: 6955-6960.

Mark BG, McKenzie JM, Gomez J. 2005. Hydrochemical evaluation of changing glacier meltwater contribution to stream discharge: Callejon de Huaylas, Peru. Hydrological Sciences Journal, 50: 975-987.

Mark BG, Seltzer GO. 2003. Tropical glacier meltwater contribution to stream discharge: a case study in the Cordillera Blanca, Peru. Journal of Glaciology, 49: 271-281. 
McClymont AF, Roy JW, Hayashi M, Bentley LR, Maurer H, Langston G. 2011. Investigating groundwater flow paths within proglacial moraine using multiple geophysical methods. Journal of Hydrology, 399: 57-69.

McKenzie JM, Mark BG, Thompson LG, Schotterer U, Lin PN. 2010. A hydrogeochemical survey of Kilimanjaro (Tanzania): Implications for water sources and ages. Hydrogeology Journal, 18: 985-995.

McKenzie JM, Siegel DI, Patterson W, McKenzie DJ. 2001. A geochemical survey of spring water from the main Ethiopian rift valley, southern Ethiopia: Implications for wellhead protection. Hydrogeology Journal, 9: 265-272.

McNulty BA, Farber DL, Wallace GS, Lopez R, Palacios O. 1998. Role of plate kinematics and plate-slip-vector partitioning in continental magmatic arcs: Evidence from the Cordillera Blanca, Peru. Geology, 26: 827-830.

Menzies J. 2002. Modern and Past glacial Environment. Butterworth - Heinemann Editions. Meriano M, Eyles N. 2003. Groundwater flow through Pleistocene glacial deposits in the rapidly urbanizing Rouge River-Highland Creek watershed, City of Scarborough, southern Ontario, Canada. Hydrogeology Journal, 11: 288-303

Muir DL, Hayashi M, McClymont AF. 2011. Hydrological storage and transmission characteristics of an alpine talus. Hydrological Processes, 25: 2954-2966.

Myers JS. 1975. Vertical crustal movements of Andes in Peru. Nature, 254: 672-674.

Ofterdinger US, Balderer W, Loew S, Renard P. 2004. Environmental isotopes as indicators for groundwater recharge to fractured granite. Ground Water, 42: 868-879.

Parisi S, Paternoster M, Kohfahl C, Pekdeger A, Meyer H, Hubberten HW, Spilotro G, Mongelli G. 2011. Groundwater recharge areas of a volcanic aquifer system inferred from hydraulic, hydrogeochemical and stable isotope data: Mount Vulture, southern Italy. Hydrogeology Journal, 19: 133-153.

Parriaux A, Nicoud G. 1993. Glacial deposits and groundwater. An example with a northwestern alpine context. Quaternaire, 4: 61-67.

Peterson TC, Baringer MO, Diamond HJ, Fogt RL, Levy JM, Richter-Menge J, Thorne PW, Vincent LA, Watkins AB. 2009. State of the climate in 2008. Bulletin of the American Meteorological Society, 90: S1-S196.

Petford N, Atherton MP. 1992. Granitoid Emplacement and Deformation Along a Major Crustal Lineament - The Cordillera Blanca, Peru. Tectonophysics, 205: 171-185.

Pouyaud B, Zapata M, Yerren J, Gomez J, Rosas G, Suarez W, Ribstein P. 2005. On the future of the water resources from glacier melting in the Cordillera Blanca, Peru. Hydrological Sciences Journal, 50: 999-1022.

Rabatel A, Francou B, Soruco A, Gomez J, Cáceres B, Ceballos JL, Basantes R, Vuille M, Sicart JE, Huggel C, Scheel M, Lejeune Y, Arnaud Y, Collet M, Condom T, Consoli G, Favier V, Jomelli V, Galarraga R, Ginot P, Maisincho L, Mendoza J, Ménégoz M, Ramirez E, Ribstein P, Suarez W, Villacis M, Wagnon P. 2013. Current state of glaciers in the tropical Andes: A multi-century perspective on glacier evolution and climate change. Cryosphere, 7: 81-102.

Racoviteanu. 2005. GLIMS Glacier Database. National Snow and Ice Data Center/World Data Center for Glaciology.

Rademacher LK, Clark JF, Hudson GB, Erman DC, Erman NA. 2001. Chemical evolution of shallow groundwater as recorded by springs, Sagehen basin; Nevada County, California. Chemical Geology, 179: 37-51.

Risi C, Bony S, Vimeux F. 2008. Influence of convective processes on the isotopic composition ( $\hat{I}^{\prime} 180$ and $\left.\hat{I}^{\prime} \mathrm{D}\right)$ of precipitation and water vapor in the tropics: 2. Physical interpretation of the amount effect. Journal of Geophysical Research D: Atmospheres, 113. DOI: 10.1029/2008JD009943. 
Robinson ZP, Fairchild IJ, Russell AJ. 2008. Hydrogeological implications of glacial landscape evolution at Skeioararsandur, SE Iceland. Geomorphology, 97: 218-236.

Rodbell DT. 1993. The Timing of the Last Deglaciation in Cordillera Oriental, Northern Peru, Based on Glacial Geology and Lake Sedimentology. Geological Society of America Bulletin, 105: 923-934.

Roy JW, Hayashi M. 2009. Groundwater flow patterns of glacial moraine features in an alpine environment. In: IAHS-AISH Publication, pp: 126-132.

Roy JW, Hayashi M. 2009. Multiple, distinct groundwater flow systems of a single morainetalus feature in an alpine watershed. Journal of Hydrology, 373: 139-150.

Rozanski K, Araguas L. 1995. Spatial and temporal variability of stable isotope composition of precipitation over the South American Continent. Bulletin - Institut Francais d'Etudes Andines, 24: 379-390.

Ryu JS, Lee KS, Chang HW. 2007. Hydrochemistry and isotope geochemistry of Song Stream, a headwater tributary of the South Han River, South Korea. Geosciences Journal, 11: 157-164.

Sass O, Wetzel KF, Friedmann A. 2006. Landscape dynamics of sub-alpine forest fire slopes in the Northern Alps - Preliminary results. Zeitschrift fur Geomorphologie, Supplementband, 142: 207-227.

Saylor JE, Mora A, Horton BK, Nie J. 2009. Controls on the isotopic composition of surface water and precipitation in the Northern Andes, Colombian Eastern Cordillera. Geochimica et Cosmochimica Acta, 73: 6999-7018.

Selveradjou S-K, Montanarella L, Spaargaren O, Dent D. 2005. European Digital Archive of Soil Maps (EuDASM). Office of the Official Publications of the European Communities.

Shrestha RR, Simonovic SP. 2010. Fuzzy set theory based methodology for the analysis of measurement uncertainties in river discharge and stage. Canadian Journal of Civil Engineering, 37: 429-439.

Sidle WC. 1998. Environmental isotopes for resolution of hydrology problems. Environmental Monitoring and Assessment, 52: 389-410.

Smith JA, Rodbell DT. 2010. Cross-cutting moraines reveal evidence for north atlantic influence on glaciers in the tropical Andes. Journal of Quaternary Science, 25: 243248.

Smith JA, Seltzer GO, Farber DL, Rodbell DT, Finkel RC. 2005. Early local last glacial maximum in the tropical Andes. Science, 308: 678-681.

Squeo FA, Warner BG, Aravena R, Espinoza D. 2006. Bofedales: high altitude peatlands of the central Andes. Reista Chilena de Historia Natural, 79: 245-255.

Stichler W, Schotterer U, Fröhlich K, Ginot P, Kull C, Gäggeler H, Pouyaud B. 2001. Influence of sublimation on stable isotope records recovered from high-altitude glaciers in the tropical Andes. Journal of Geophysical Research: Atmospheres, 106. DOI: $10.1029 / 2001 J D 900179$.

Strauch G, Oyarzun J, Fiebig-Wittmaack M, Gonzalez E, Weise S. 2006. Contributions of the different water sources to the Elqui river runoff (northern Chile) evaluated by H/O isotopes. Isotopes in Environmental and Health Studies, 42: 303-322.

Suarez W, Chevallier P, Pouyaud B, Lopez P. 2008. Modelling the water balance in the glacierized Paron Lake basin (White Cordillera, Peru). Hydrological Sciences Journal, 53: $266-277$.

Van de Griend AA, Seyhan E, Engelen GB, Geirnaert W. 1986. Hydrological characteristics of an Alpine glacial valley in the North Italian Dolomites. Journal of Hydrology, 88: 275-299. 
Vimeux F, Gallaire R, Bony S, Hoffmann G, Chiang JCH. 2005. What are the climate controls on I'D in precipitation in the Zongo Valley (Bolivia)? Implications for the Illimani ice core interpretation. Earth and Planetary Science Letters, 240: 205-220.

Vimeux F, Tremoy G, Risi C, Gallaire R. 2011. A strong control of the South American SeeSaw on the intra-seasonal variability of the isotopic composition of precipitation in the Bolivian Andes. Earth and Planetary Science Letters, 307: 47-58.

Vuille M, Bradley RS, Healy R, Werner M, Hardy DR, Thompson LG, Keimig F. 2003. Modeling $\delta 180$ in precipitation over the tropical Americas: 2. Simulation of the stable isotope signal in Andean ice cores. Journal of Geophysical Research: Atmospheres, 108. DOI: $10.1029 / 2001 J D 002039$.

Vuille M, Werner M. 2005. Stable isotopes in precipitation recording South American summer monsoon and ENSO variability: Observations and model results. Climate Dynamics, 25: 401-413.

Wassenaar LI, Athanasopoulos P, Hendry MJ. 2011. Isotope hydrology of precipitation, surface and ground waters in the Okanagan Valley, British Columbia, Canada. Journal of Hydrology, 411: 37-48.

Williams MW, Knauf M, Caine N, Liu F, Verplanck PL. 2006. Geochemistry and source waters of rock glacier outflow, Colorado Front Range. Permafrost and Periglacial Processes, 17: 13-33.

Windhorst D, Waltz T, Timbe E, Frede H, Breuer L. 2013. Impact of elevation and weather patterns on the isotopic composition of precipitation in the tropical montane rainforest. Hydrology and Earth System Sciences, 17: 409-419.

Yamanaka M, Nakano T, Tase N. 2005. Hydrogeochemical evolution of confined groundwater in northeastern Osaka Basin, Japan: estimation of confined groundwater flux based on a cation exchange mass balance method. Applied Geochemistry, 20: 295-316.

Yang Q, Xiao H, Zhao L, Yang Y, Li C, Yin L. 2011. Hydrological and isotopic characterization of river water, groundwater, and groundwater recharge in the Heihe River basin, northwestern China. Hydrological Processes, 25: 1271-1283.

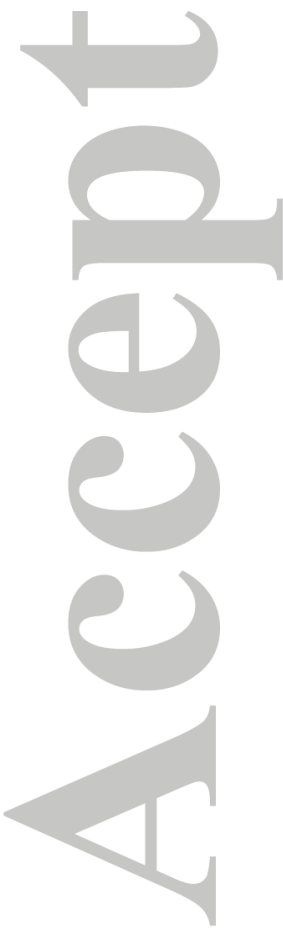


Table 1. Geospatial characteristics of the watersheds in this study. The glacierized areas and the median elevations were calculated using the 2005 GLIMS database (Racoviteanu, 2005). The pampa area was determined using an ASTER-derived DEM with a cell size of $30 \mathrm{~m}$. The bedrock type was estimated from geological maps (Selveradjou et al., 2005).

\begin{tabular}{|c|c|c|c|c|c|c|c|c|}
\hline \multirow{2}{*}{ Basin } & \multirow{2}{*}{$\begin{array}{c}\text { Basin area } \\
\left(\mathrm{km}^{2}\right)\end{array}$} & \multirow{2}{*}{$\begin{array}{l}\text { Outflow } \\
\text { elevation } \\
\text { (m) }\end{array}$} & \multirow{2}{*}{$\begin{array}{l}\text { Glaciated } \\
\text { area }(\%)\end{array}$} & \multirow{2}{*}{$\begin{array}{c}\text { Glacier } \\
\text { median } \\
\text { elevation } \\
\quad(\mathrm{m})\end{array}$} & \multirow{2}{*}{$\begin{array}{c}\text { Pampa } \\
\text { area }(\%)\end{array}$} & \multicolumn{3}{|c|}{ Bedrock type (\%) } \\
\hline & & & & & & Plutonic & Volcanic & Sedimentary \\
\hline Llanganuco & 63.76 & 3838 & $41.5+/-2$ & 5231 & 1.2 & 50 & 0 & 50 \\
\hline Quilcayhuanca & 87.66 & 3835 & $20.5+/-1$ & 5139 & 4.1 & 15 & 0 & 85 \\
\hline Yanamarey & 26.93 & 4005 & $6.3+/-0.5$ & 4946 & 9.4 & 5 & 0 & 95 \\
\hline Pumapampa & 52.65 & 4274 & $16.1+/-1$ & 5128 & 11.6 & 0 & 65 & 35 \\
\hline
\end{tabular}

Table 2. Multivariate variance analysis (ANOVA) results for the 2008 MELT, GW, GWS and GWP samples from all sites performed on the 13 tracers. Two factors were tested: Source, which represents the different sources of water, and Site, which represents the sampled watershed. Statistically significant dependences (p-values $<0.05$ ) are highlighted in bold.

\begin{tabular}{|c|c|c|c|c|}
\hline \multirow[b]{2}{*}{ Tracer } & \multicolumn{2}{|c|}{ Source } & \multicolumn{2}{|c|}{ Site } \\
\hline & $F$ factor & $P$ & $F$ factor & $P$ \\
\hline $\mathrm{SO}_{4}{ }^{2-} / \Sigma A^{-}$ & 9.41 & 0.0008 & 0.39 & 0.7652 \\
\hline $\mathrm{HCO}_{3}^{-} / \Sigma A^{-}$ & 10.78 & 0.0004 & 0.33 & 0.8008 \\
\hline$F / \Sigma A^{-}$ & 0.68 & 0.5776 & 8.00 & 0.0018 \\
\hline $\mathrm{Cl}^{-} / \Sigma \mathrm{A}^{-}$ & 0.49 & 0.6952 & 0.71 & 0.5611 \\
\hline $\mathrm{Ca}^{2+} / \Sigma \mathrm{C}^{+}$ & 2.22 & 0.1256 & 0.84 & 0.4930 \\
\hline $\mathrm{Mg}^{2+} / \Sigma \mathrm{C}^{+}$ & 1.57 & 0.2358 & 2.03 & 0.1504 \\
\hline $\mathrm{Na}^{+} / \Sigma \mathrm{C}^{+}$ & 0.87 & 0.4759 & 0.81 & 0.5082 \\
\hline$K^{+} / \Sigma C^{+}$ & 2.55 & 0.0923 & 0.46 & 0.7150 \\
\hline $\mathrm{Fe}^{2+, 3+} / \Sigma \mathrm{C}^{+}$ & 3.60 & 0.0368 & 1.32 & 0.3038 \\
\hline$\left(\mathrm{Ca}^{2+}+\mathrm{Mg}^{2+}\right) / \Sigma \mathrm{C}^{+}$ & 3.68 & 0.0346 & 1.22 & 0.3346 \\
\hline$\left(N a^{+}+K^{+}\right) / \Sigma C^{+}$ & 0.84 & 0.4905 & 0.65 & 0.5961 \\
\hline $\mathrm{SO}_{4}^{2-} /\left(\mathrm{Na}^{+}+\mathrm{K}^{+}\right)$ & 2.70 & 0.0806 & 1.48 & 0.2573 \\
\hline $\mathrm{SO}_{4}^{2-} /\left(\mathrm{Ca}^{2+}+\mathrm{Mg}^{2+}\right)$ & 2.78 & 0.0750 & 1.28 & 0.3151 \\
\hline
\end{tabular}


Table 3. Altitude effect of $\delta^{18} \mathrm{O}$ and $\delta^{2} \mathrm{H}$ in precipitation reported for the tropical Andes. Information in italics is reproduced from Windhorst et al. (2013), and the values in bold represent the lowest slopes found in the literature.

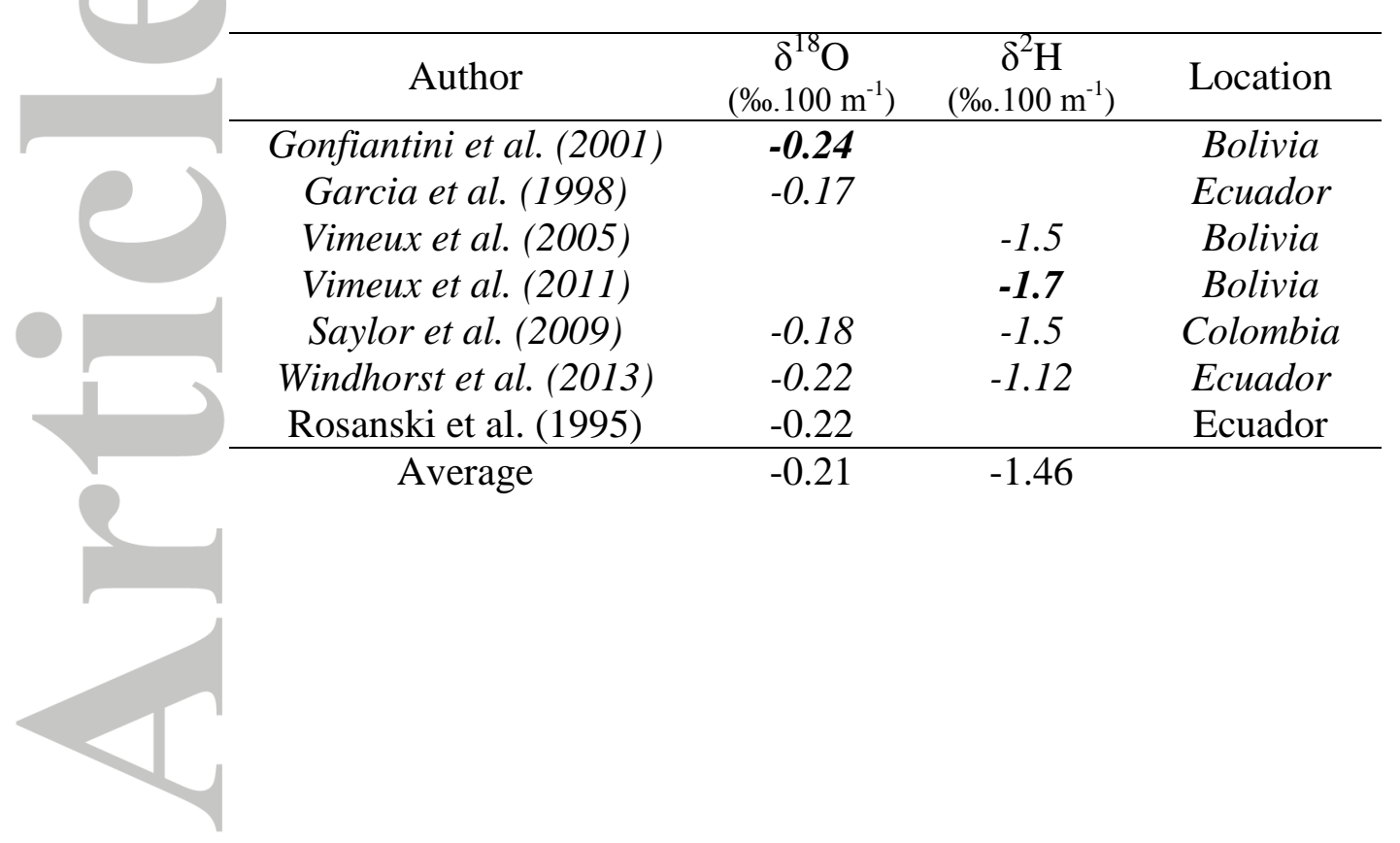

Table 4. $\delta^{18} \mathrm{O}$ and $\delta^{2} \mathrm{H}$ based estimates of the minimum average elevations of the recharge areas for the 2008 spring samples. All of the absolute elevations are expressed in meters above sea level, and the isotopic values are expressed in \%o VSMOW. "Min $\Delta$ elevation," which is expressed in meters, corresponds to the minimum recharge elevation minus the sampling elevation.

\begin{tabular}{|cc|ccc|ccc|} 
& & \multicolumn{3}{|c|}{$\boldsymbol{\delta}^{\mathbf{1 8}}$ O-based estimation } & \multicolumn{3}{c|}{$\boldsymbol{\delta}^{\mathbf{2}}$-based estimation } \\
\hline Spring & $\begin{array}{c}\text { sampling } \\
\text { elevation }\end{array}$ & $\delta^{18} \mathrm{O}$ & $\begin{array}{c}\text { Min } \\
\text { recharge } \\
\text { elevation }\end{array}$ & $\begin{array}{c}\text { Min } \boldsymbol{\Delta} \\
\text { elevation }\end{array}$ & $\delta^{2} \mathrm{H}$ & $\begin{array}{c}\text { Min } \\
\text { recharge } \\
\text { elevation }\end{array}$ & $\begin{array}{c}\text { Min } \boldsymbol{\Delta} \\
\text { elevation }\end{array}$ \\
\hline QGWS1 & 4085 & -15.79 & 4542 & $\mathbf{4 5 7}$ & -122.27 & 4705 & $\mathbf{6 2 0}$ \\
YGWS1 & 4050 & -15.2 & 4296 & $\mathbf{2 4 6}$ & -115.65 & 4316 & $\mathbf{2 6 6}$ \\
PGWS1 & 4488 & -16.12 & 4680 & $\mathbf{1 9 2}$ & -122.32 & 4708 & $\mathbf{2 2 0}$ \\
PGWS2 & 4295 & -16.19 & 4709 & $\mathbf{4 1 4}$ & -120.7 & 4613 & $\mathbf{3 1 8}$
\end{tabular}


Table 5. Main characteristics and HBCM-based contribution estimates for the study areas. "GW" represents groundwater, and "MELT" stands for glacial melt water.

\begin{tabular}{|c|c|c|c|c|c|c|c|c|}
\hline \multirow{2}{*}{ Study area } & \multirow{2}{*}{$\begin{array}{l}\text { Total } \\
\text { area } \\
\left(\mathrm{km}^{2}\right)\end{array}$} & \multirow{2}{*}{$\begin{array}{l}\text { Total area } \\
\text { (\% of true } \\
\text { watershed })\end{array}$} & \multirow{2}{*}{$\begin{array}{c}\text { Glacial area } \\
\text { (\% of the } \\
\text { study area) }\end{array}$} & \multicolumn{4}{|c|}{ HBCM estimates $\left(\mathrm{m}^{3} / \mathrm{s}\right)$} & \multirow{2}{*}{$\begin{array}{c}\text { GW } \\
\text { specific } \\
\text { discharge } \\
(\mathbf{m m} / \mathbf{d})\end{array}$} \\
\hline & & & & $\begin{array}{l}\mathrm{GW} \\
\max \end{array}$ & $\begin{array}{l}\mathrm{GW} \\
\mathrm{min}\end{array}$ & $\begin{array}{l}\text { MELT } \\
\max \end{array}$ & $\begin{array}{l}\text { MELT } \\
\min \end{array}$ & \\
\hline Llanganuco* & 60.2 & 95 & $44+/-2$ & 0.55 & 0.49 & 1.56 & 1.50 & $0.74+/-0.04$ \\
\hline Quilcayhuanca* & 71.5 & 82 & $17+/-1$ & 0.38 & 0.22 & 0.37 & 0.37 & $0.36+/-0.06$ \\
\hline Yanamarey* & 26.9 & 100 & $6+/-0.5$ & 0.2 & 0.19 & 0.06 & 0.05 & $0.64+/-0.02$ \\
\hline Pumapampa* & 17.5 & 33 & $7+/-0.5$ & 0.17 & 0.12 & 0.12 & 0.07 & $0.72+/-0.11$ \\
\hline
\end{tabular}
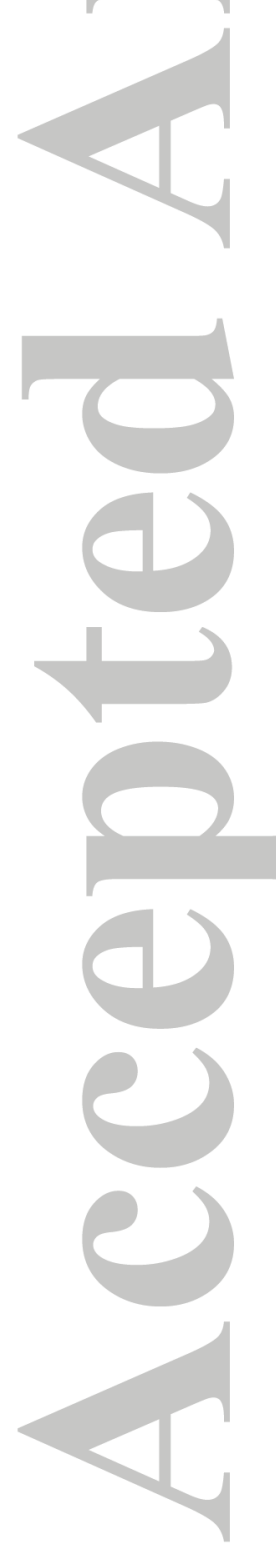

This article is protected by copyright. All rights reserved. 


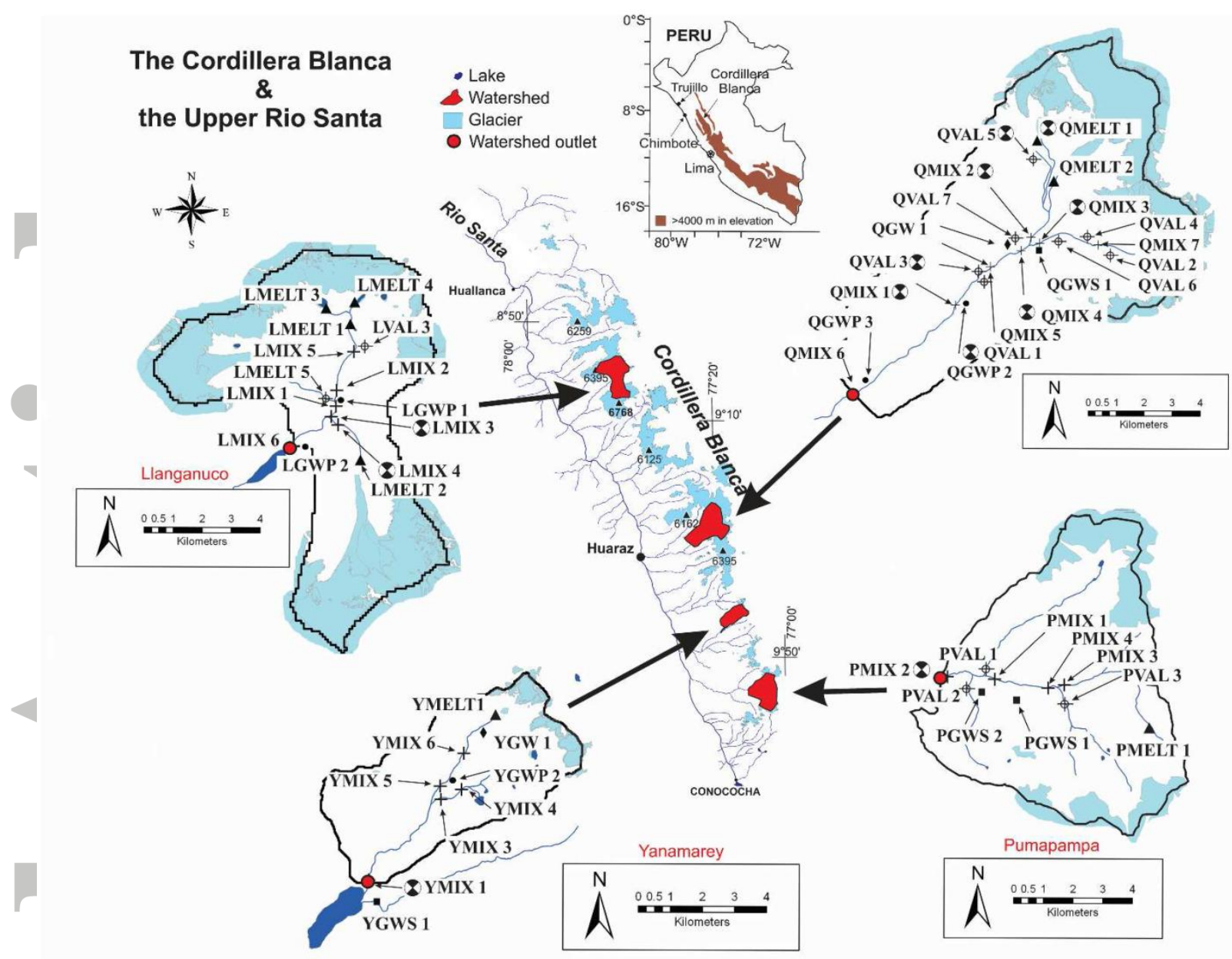

Figure 1. The Cordillera Blanca and the upper Rio Santa watershed. Samples collected at least once in 2008 are identified on the detailed maps of the watersheds. The identification numbers are structured as follows: XYYY\#, where X represents the site, YYY represents the sample type and \# represents the sequence number of the sample. The following acronyms (symbols) are used to describe the sample type: MIX (+) represents samples from the main stream, VAL $(\oplus)$ represents samples from tributaries of the main stream, MELT $(\boldsymbol{\Delta})$ represents melt water, GWS (घ) represents spring water, GWP $(\bullet)$ identifies water pumped from a shallow pampa aquifer, and GW $(\diamond)$ represents water pumped from a shallow aquifer outside the pampa areas. Gauging locations are marked with " $\bullet$." 


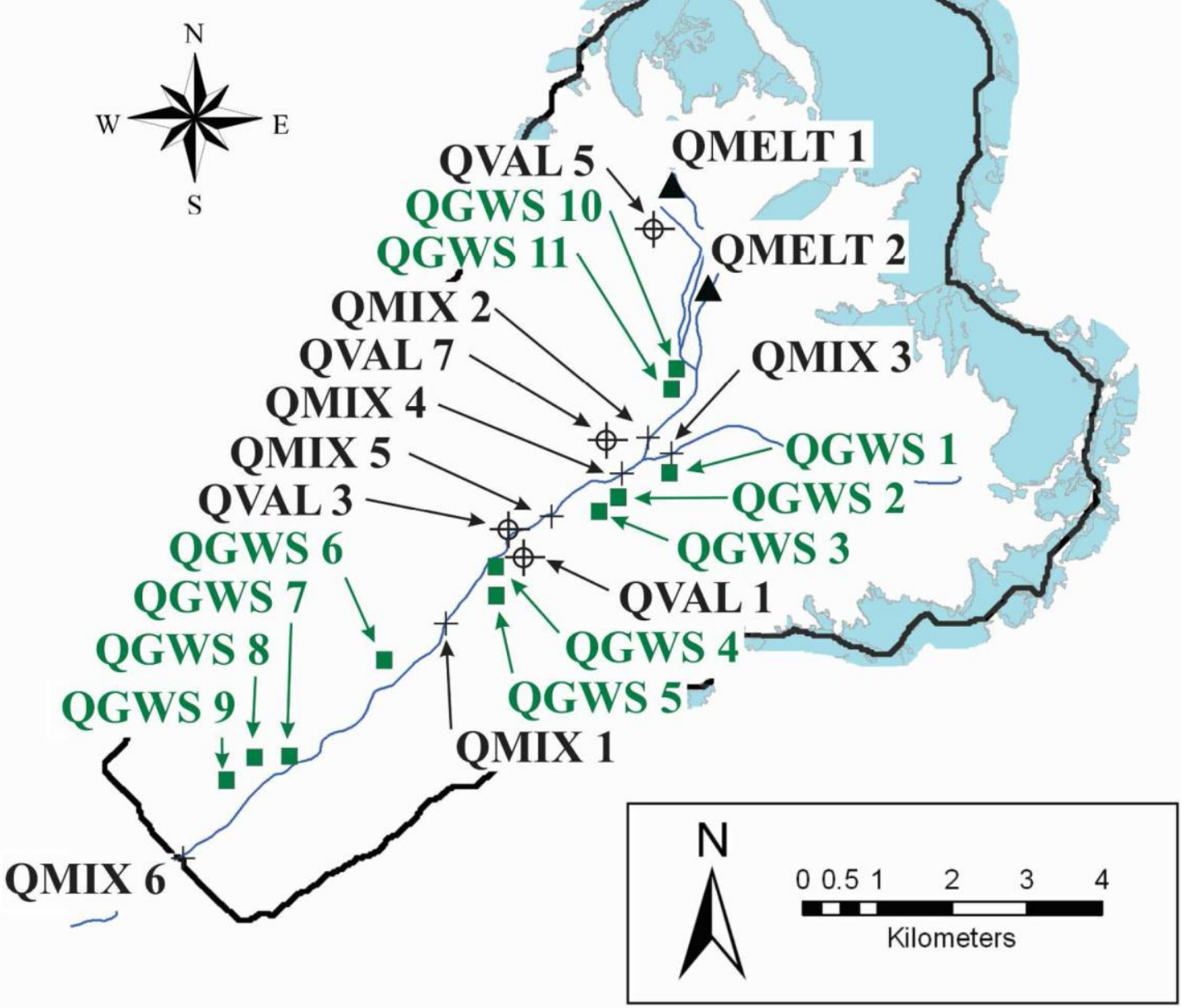

Figure 2. 2009 Quilcayhuanca sampling. The acronyms and sample identification methods are the same as in Figure 1. The labels in green represent groundwater samples. 

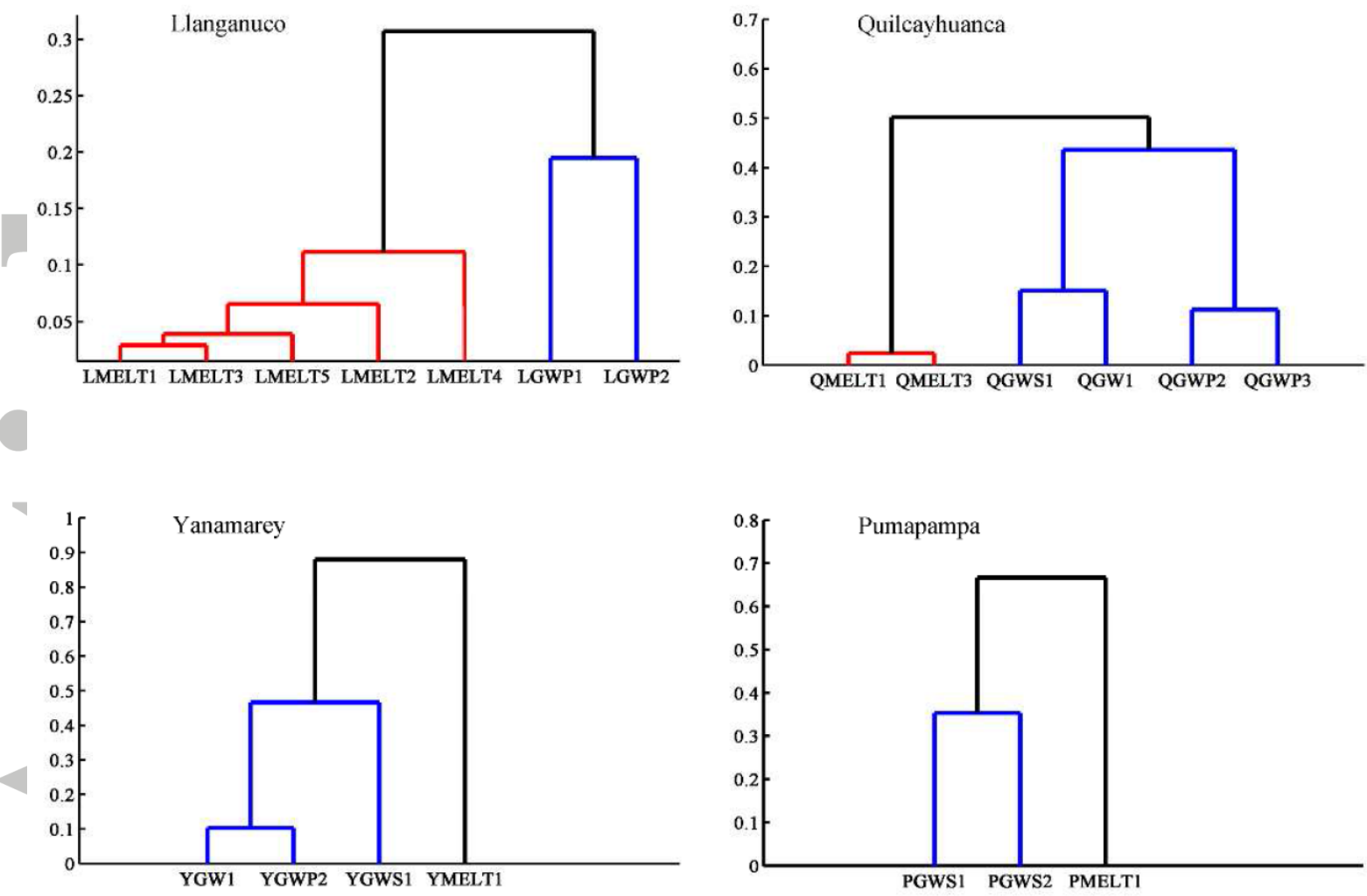

Figure 3. Verification of the effectiveness of the indicators of water sources for the 2008 samples. The dendrogram represent hierarchical clustering of the watersheds. The $\mathrm{Y}$ axes are the calculated distances (dimensionless). The red and blue lines identify melt water and groundwater clusters, respectively. 


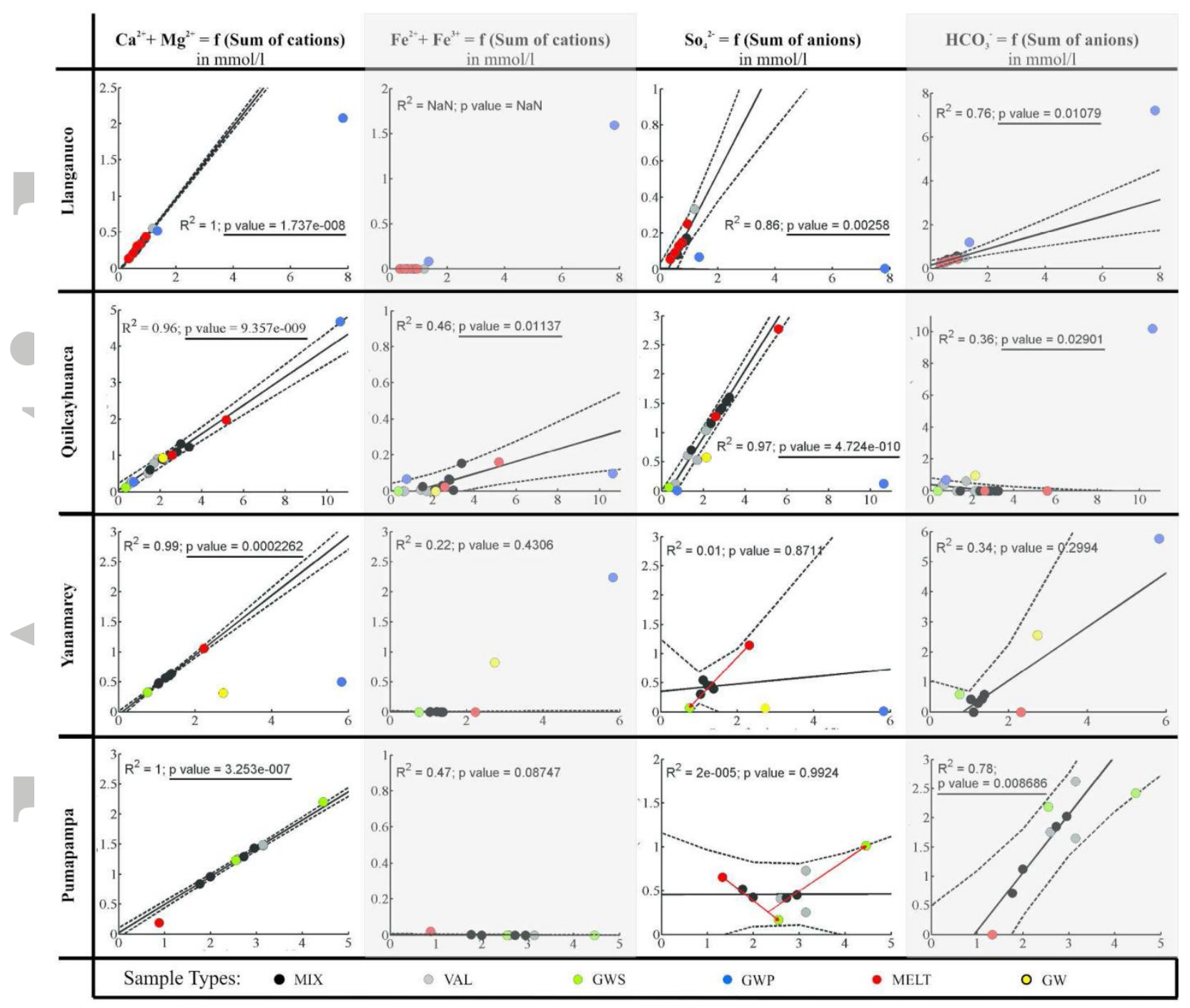

Figure 4. Scatter diagrams for each study watershed (lines) for the four tracers (columns) that are water source dependent. The solid lines represent linear regressions of the MIX and VAL samples, and the dashed lines delineate the regressions' 95\% predicted confidence intervals. $\mathrm{P}$-values under 0.05 are underlined. 


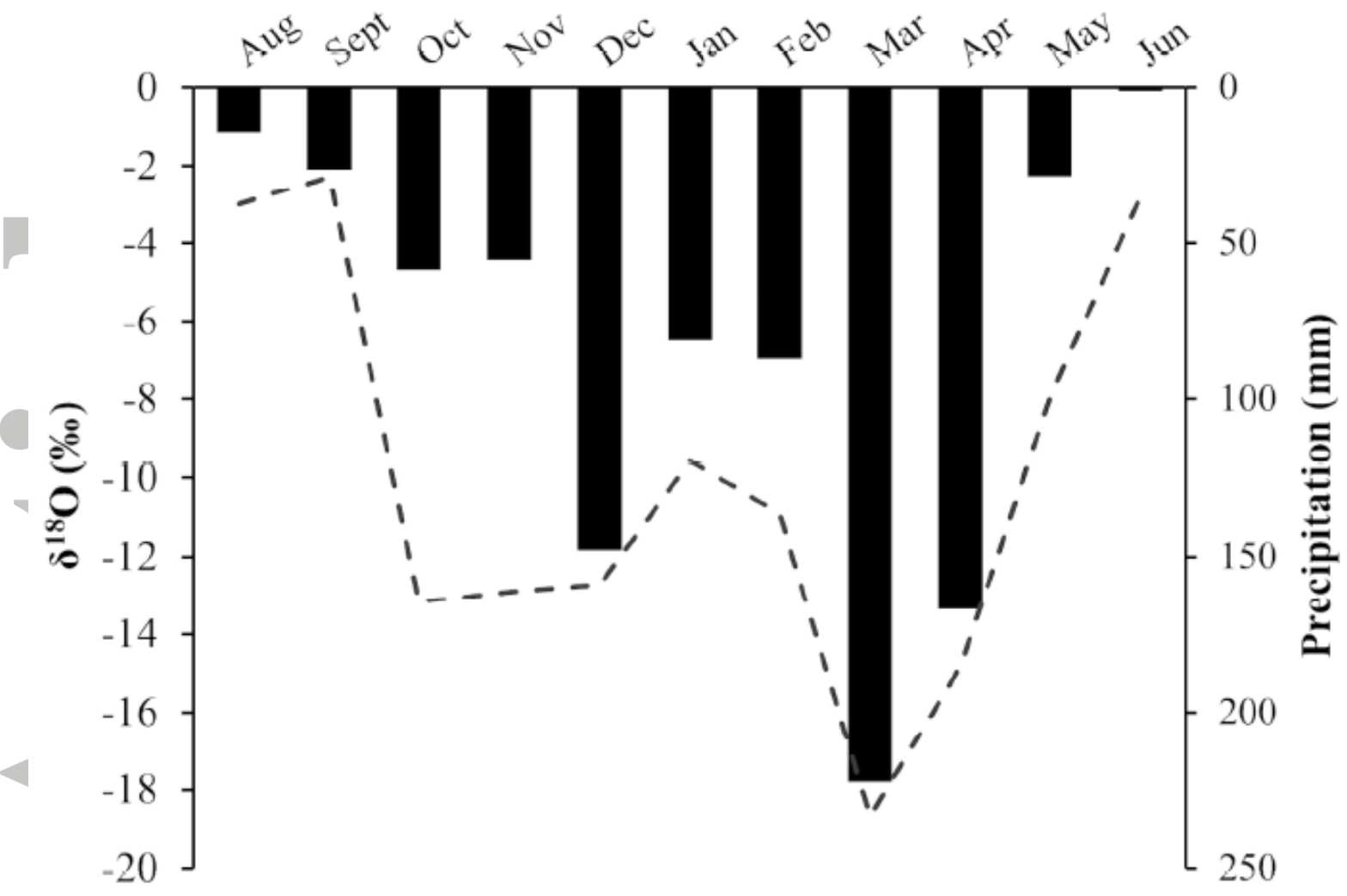

Figure 5. Precipitation volume (bars) and associated $\delta^{18} \mathrm{O}$ values (dashed line) for monthly totalized samples collected in Huaraz (Figure 1) between August 2006 and June 2007. 


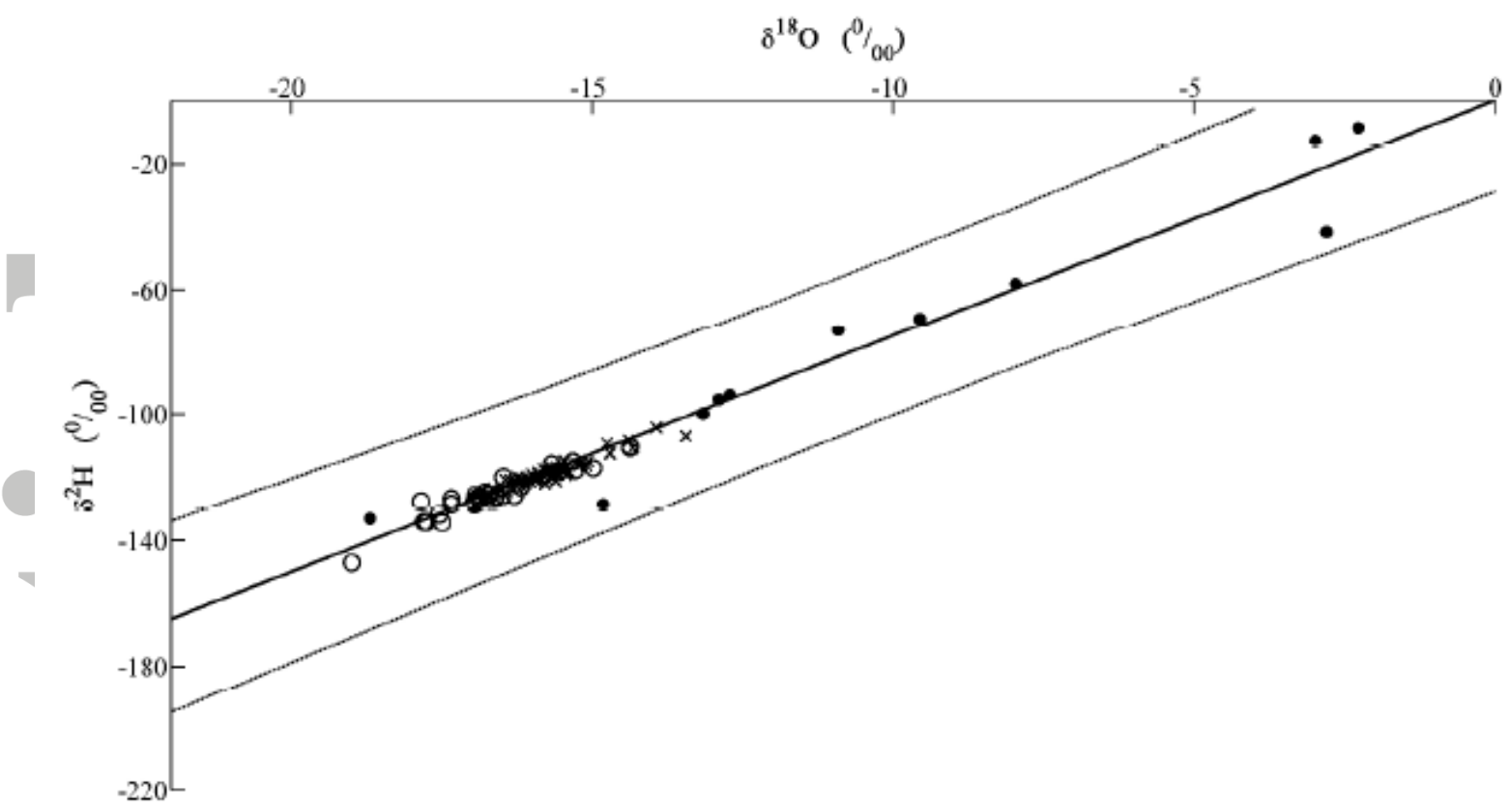

Figure 6. Meteoric waterline plot $\left(\delta^{18} \mathrm{O}\right.$ and $\delta^{2} \mathrm{H}$ in \%o VSMOW) for all samples collected in 2008 (black crosses) and 2009 (empty circles) in the watersheds. Black circles represent precipitation samples from Huaraz in 2006-2007. The solid line represents the LMWL, which was computed from precipitation samples. The $95 \%$ prediction interval associated with the LMWL is plotted with dashed lines.

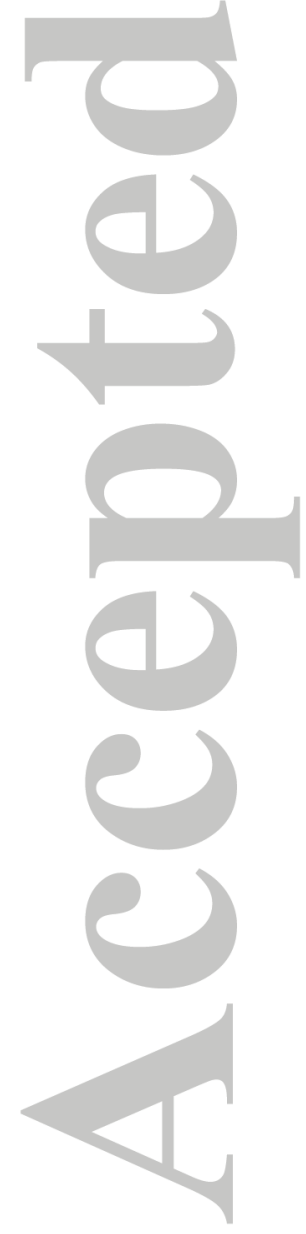



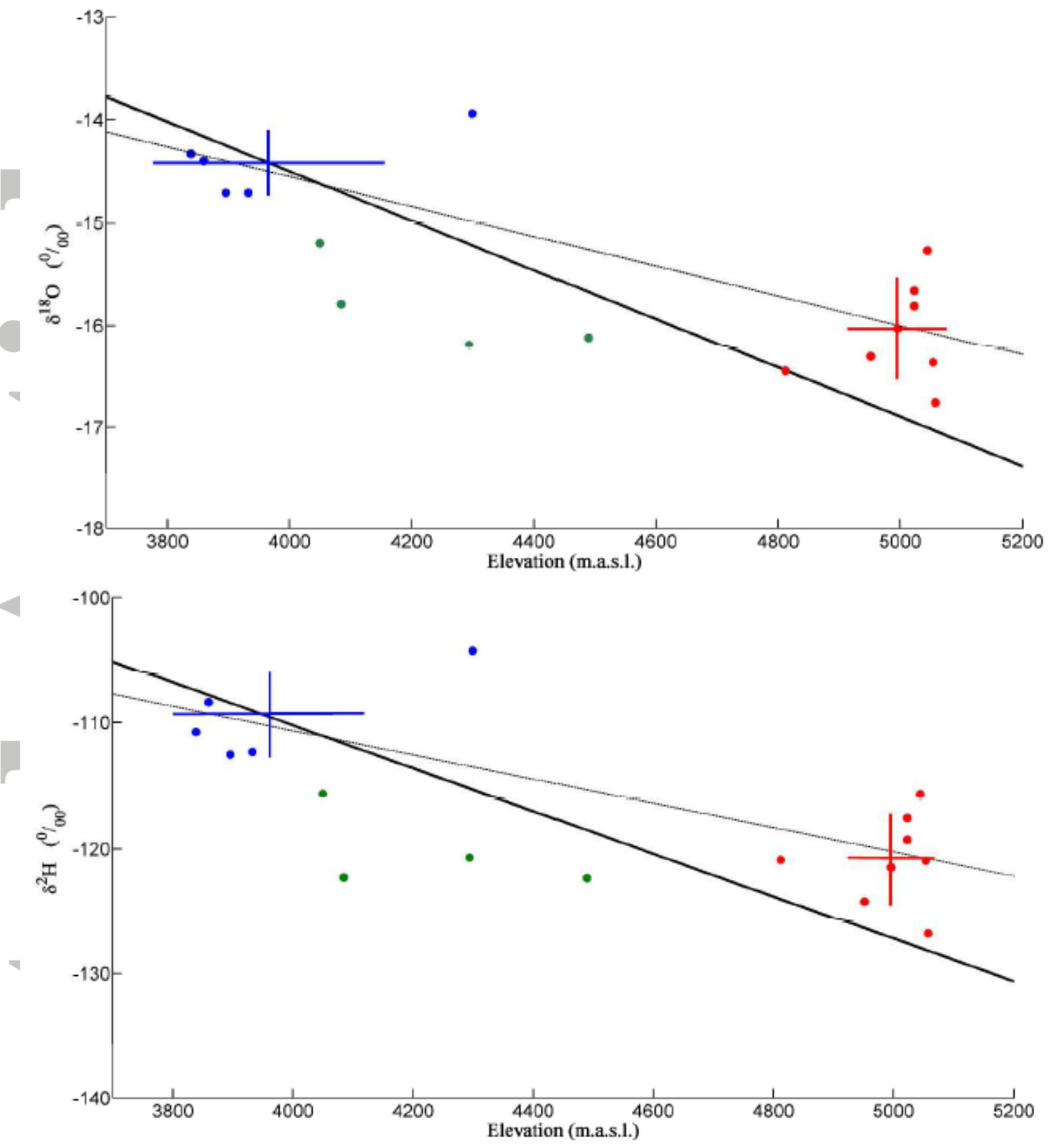

Figure 7. a) $\delta^{18} \mathrm{O}$ (\% VSMOW) versus sample elevation. b) $\delta^{2} \mathrm{H}$ (\%o VSMOW) versus sample elevation. The MELT and GWP samples are plotted in red and blue, respectively. The red and blue crosses represent the average position plus and minus one standard deviation, respectively. The GWS samples are plotted in green. The solid black line is the line of minimum mean recharge elevation. The dashed line, which represents the regression line for the individual MELT and GWP samples, is shown for reference. 


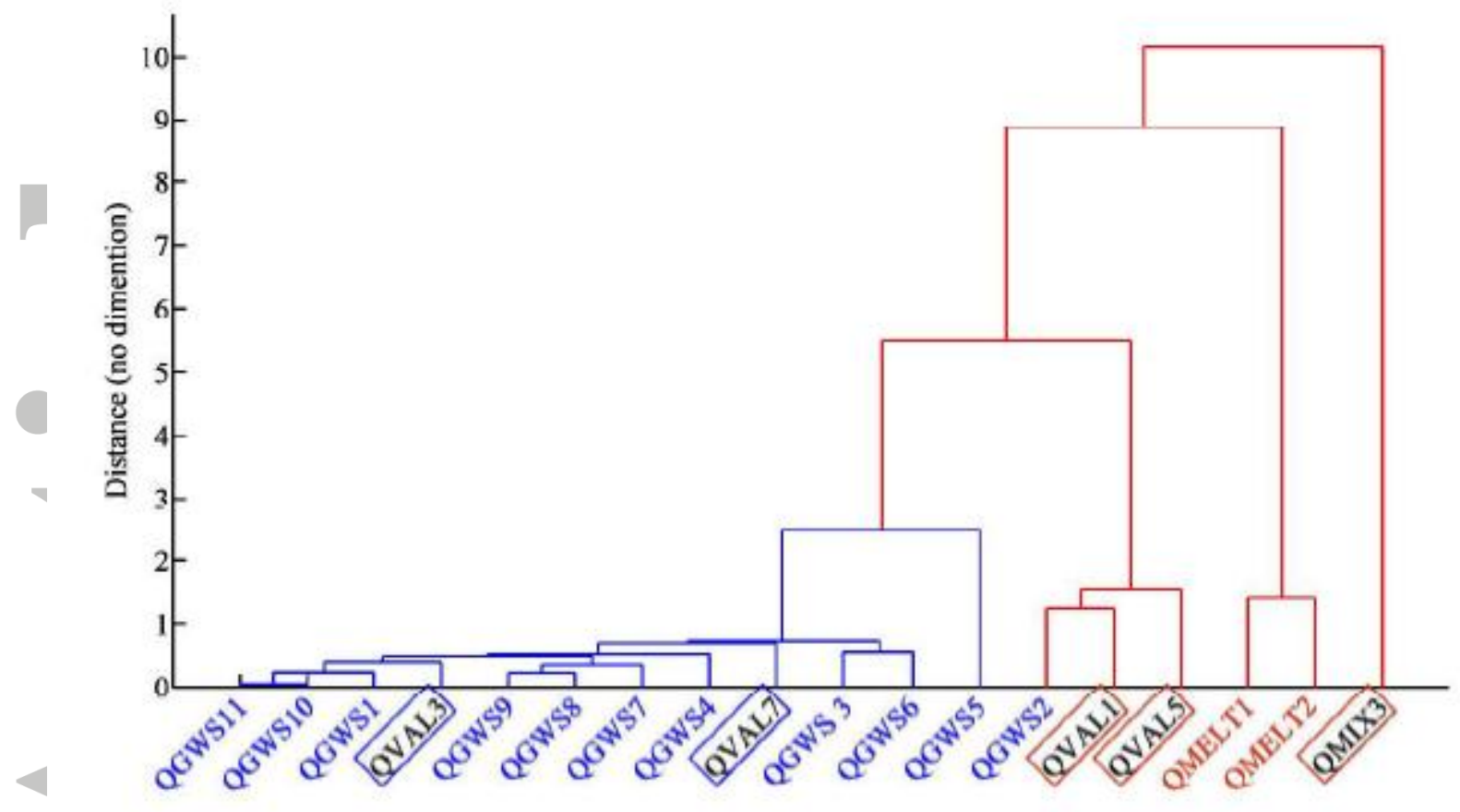

Figure 8. Dendrogram of the Quilcayhuanca samples collected during the summer of 2009. The blue lines represent the precipitation cluster, and the red lines represent the melt water cluster. Sample names written in black are streams or tributary samples used as references. 


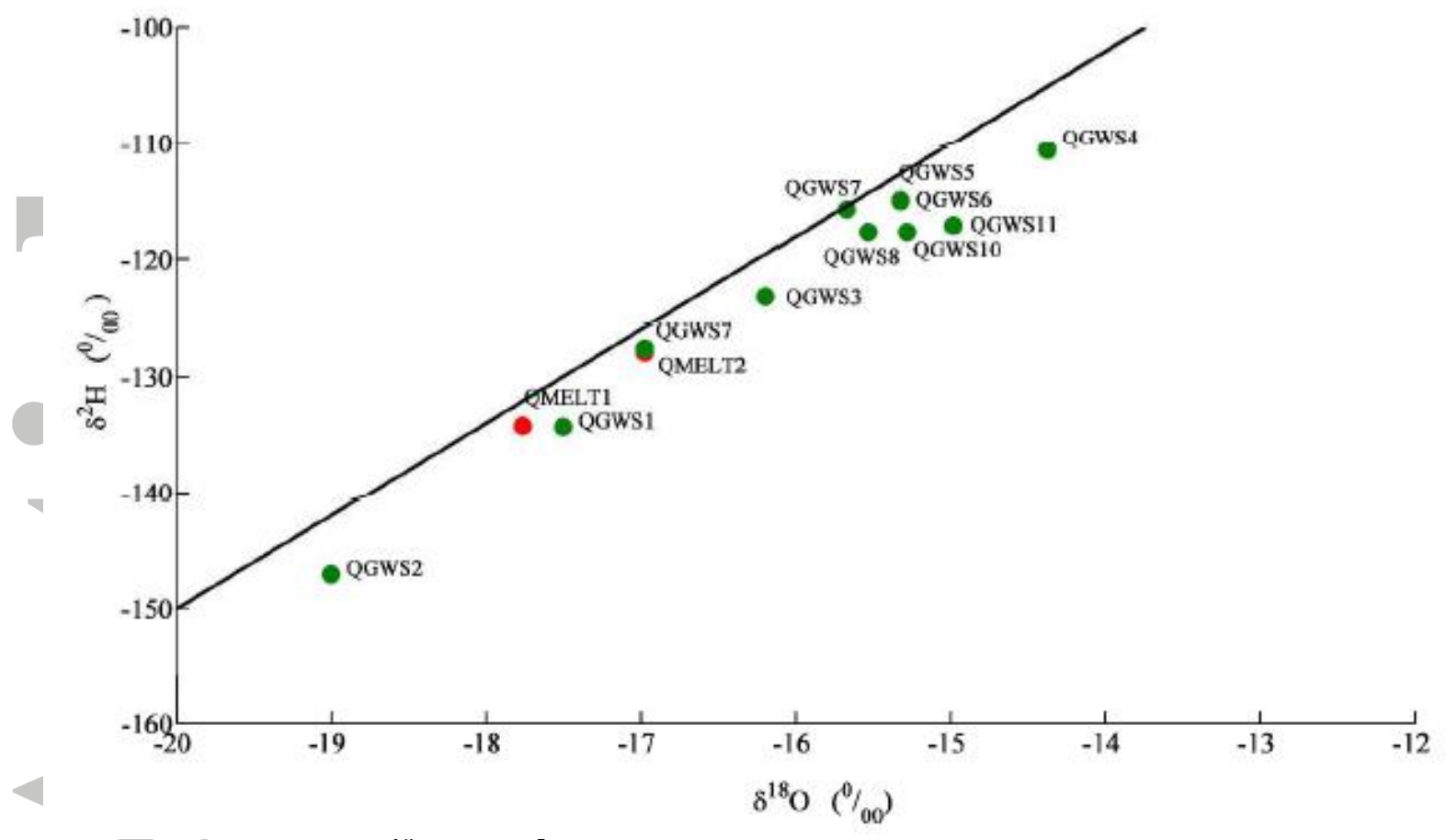

Figure 9. $\delta$-diagram $\left(\delta^{18} \mathrm{O}\right.$ and $\delta^{2} \mathrm{H}$ in \%o VSMOW) for all of the water source samples collected in 2009 in Quilcayhuanca. The MELT samples are in red, and the GWS samples are in green. The local meteoric water line calculated using the 2006 and 2007 precipitation samples is shown as a reference (black line).

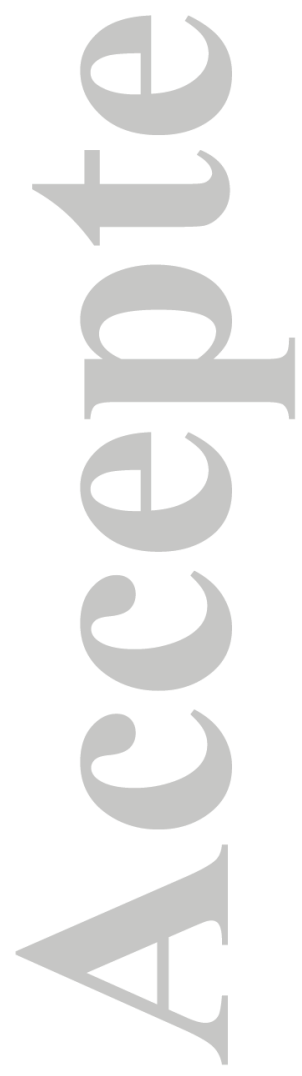

This article is protected by copyright. All rights reserved. 
a)
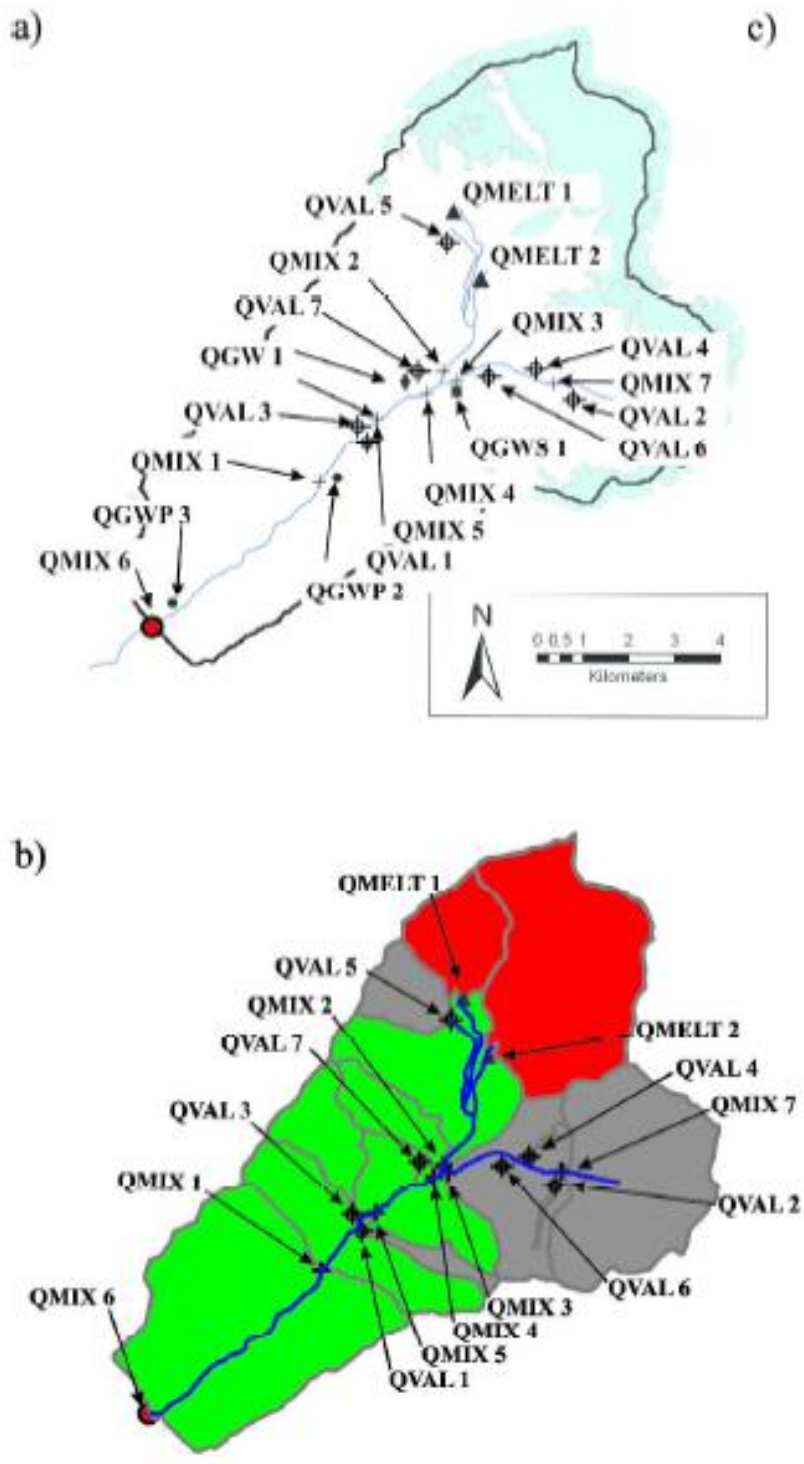

c)

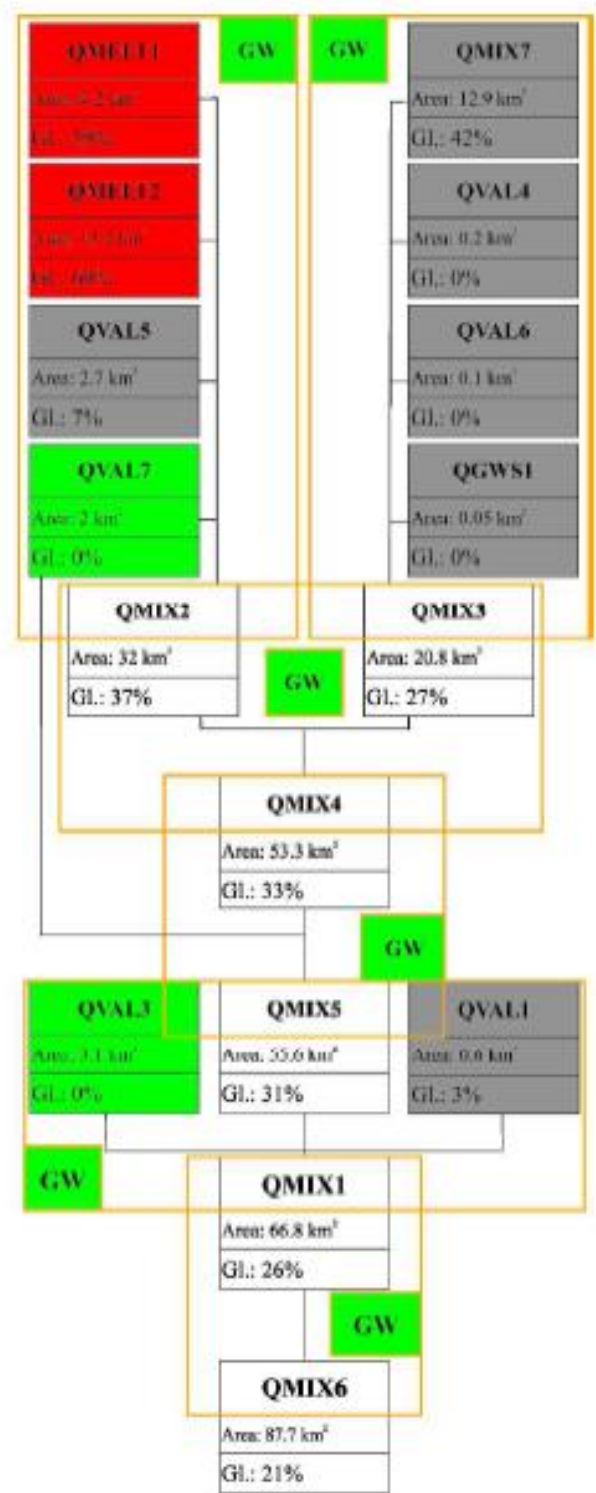

Figure 10. HBCM watershed geospatial conceptualization for the 2008 Quilcayhuanca data. a) Watershed map of sampling plan and b) corresponding delineation of sub-watersheds. Groundwater-fed sub-watersheds are shown in green, melt water-fed watersheds are in red, and gray represents non-classified sub-watersheds. c) The HBCM representation of the watershed. Individual black boxes represent sub-watersheds; they are identified by the name of the sampling point, its surface area and its percentage of glacierized surface. The color code is the same as in b). The HBCM cells are delimited by orange lines. 


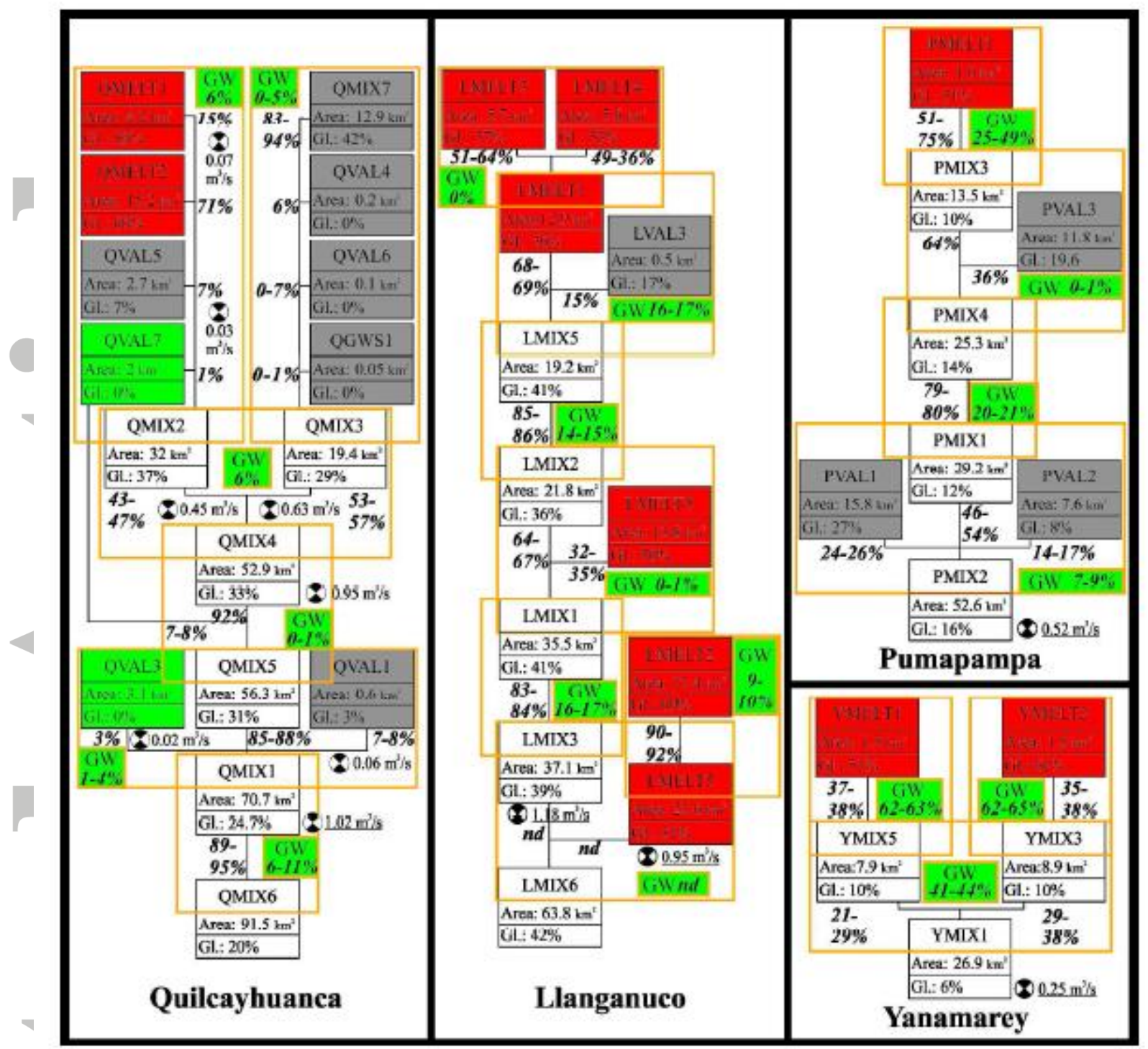

Figure 11. HBCM results for 2008. MELT, MIX and VAL samples are represented by boxes with thin black lines that include the total area (Area) and the percentage of glacierized area (Gl.) of the drainage area. Gray boxes represent unclassified drainage areas that are not accounted for in the compilation of the watershed data. Each HBCM cell is delimited by orange boxes in which the relative discharges (in \%) are written in bold characters. The groundwater contribution $(\mathrm{GW})$ is indicated as percentage within an orange-bounded green box in each cell. The symbol is used wherever discharge measurements were made, and measurement results are expressed in cubic meters per second. " $n d$ " stands for nondetermined. 


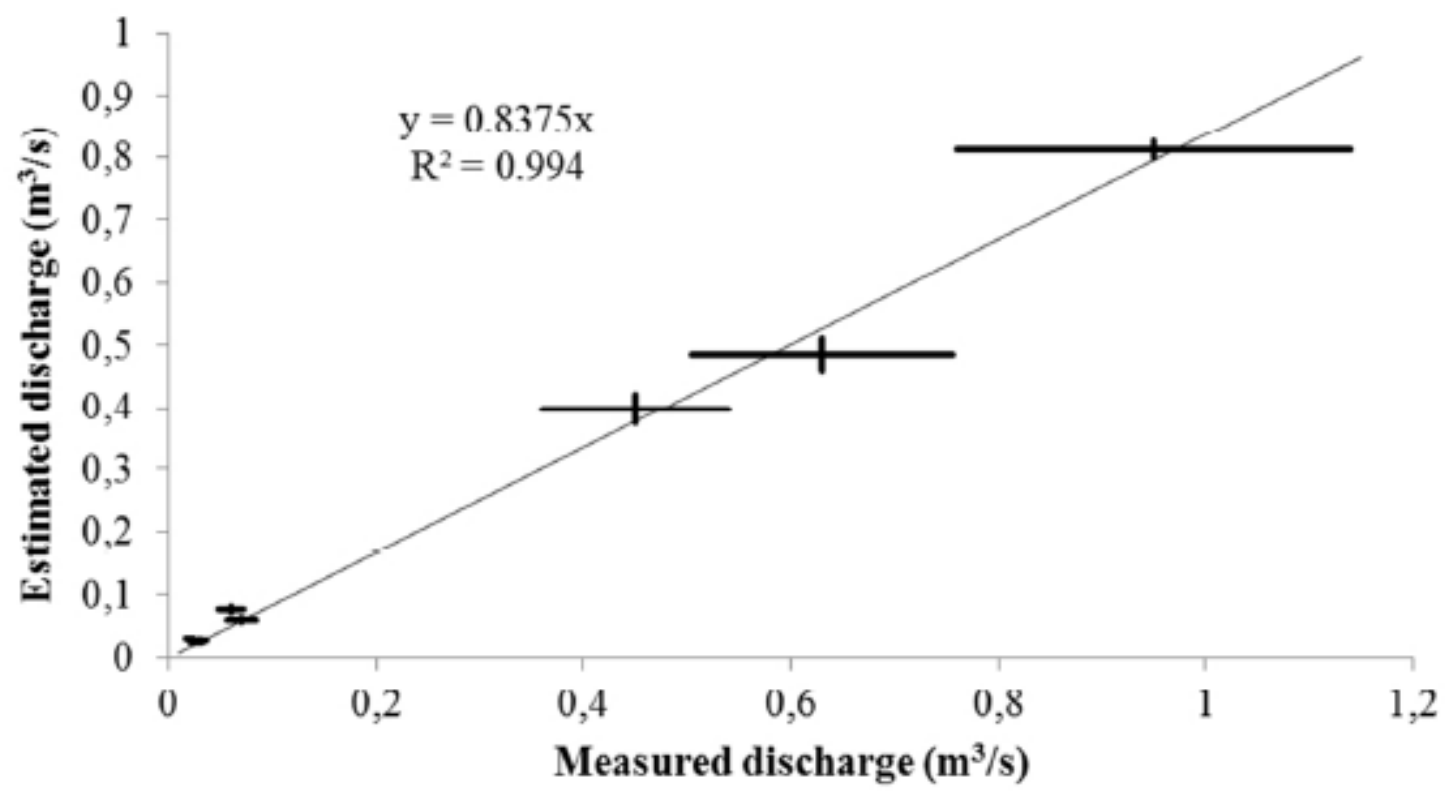

Figure 12. HBCM-estimated discharge as a function of the measured discharge. The uncertainties in the discharge measurements are represented by horizontal lines, and the vertical lines show the estimation uncertainties.

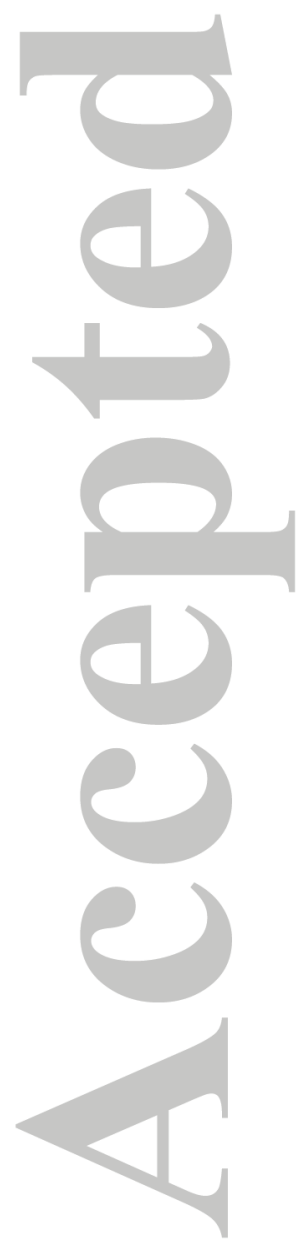

This article is protected by copyright. All rights reserved. 


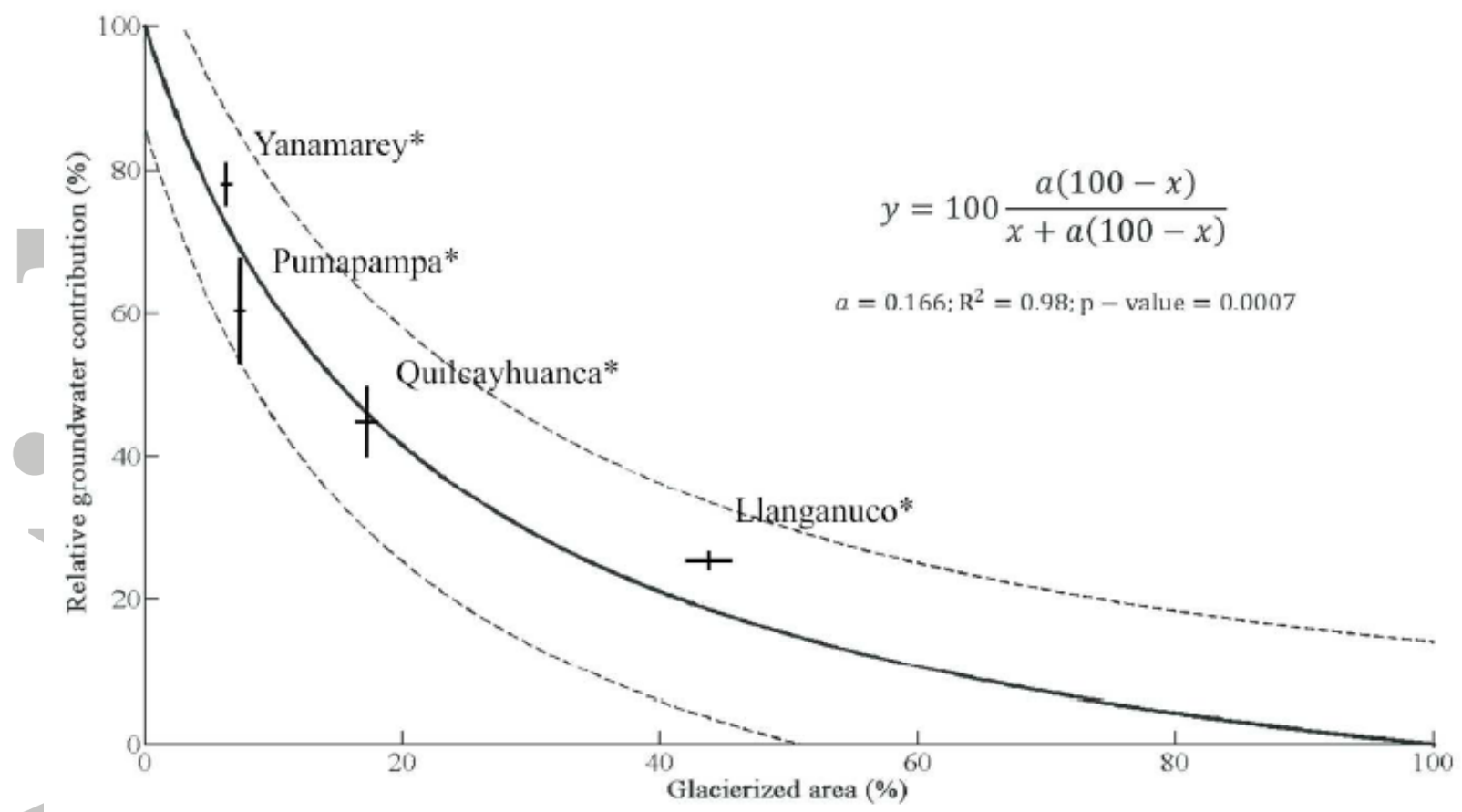

Figure 13. HBCM-estimated relative groundwater contributions to study areas discharge as a function of the glacierized area for the dry season of 2008. Each study area is presented with groundwater contribution uncertainty estimation (Table 5) and a glacierized area uncertainty of 5\% (Baraer et al., 2012). The best fit for the dilution model (equation inset on graph) is represented by the solid black line. The dashed lines delimit the regression's $95 \%$ confidence interval. 


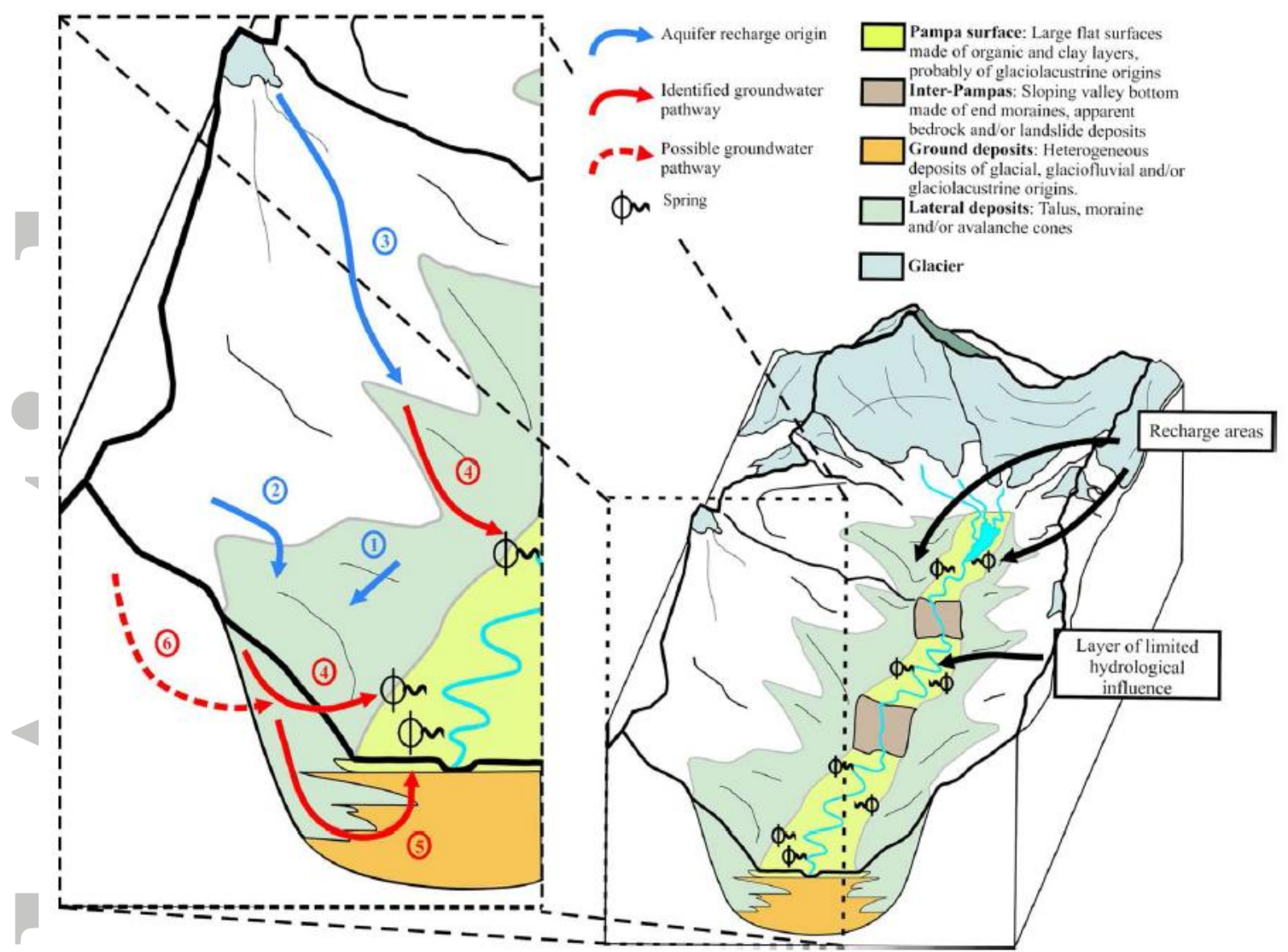

Figure 14. Conceptual model of the dry season hydrology and spring systems of the glacierized watersheds in the Cordillera Blanca. Recharge and pathway numbers are as follows: (1) direct recharge from precipitation, (2) surface runoff from overlying surfaces, (3) recharge from melt water, (4) flow through the talus slopes, (5) flow through the talus and interconnected glacial deposits and (6) possible fracture flow through bedrock. 